\title{
Historical Imperialism in Science: A Theory of the Relationship between History and Other Disciplines
}

\author{
Adjei Adjepong \\ Department of History, Faculty of Arts, College of Humanities and Legal Studies, University of Cape Coast, \\ Cape Coast
}

*Corresponding Author: Adjei Adjepong, Department of History, Faculty of Arts, College of Humanities and Legal Studies, University of Cape Coast, Cape Coast

\begin{abstract}
It is generally agreed that all the sciences, both social and natural, are related, particularly through the exchange of experiences, ideas, materials, methods, perspectives and theories. This 'give-andtake' phenomenon is, to a large extent, factual and, thus, establishes a power-equilibrium or a balance-ofpower relationship among the various disciplines. In our view, to accept this notion wholly without subjecting it to a critical scrutiny would, however, not be fair enough to history, which, from all indications, occupies a special and a privileged position among the sciences. The reason is that apart from these usual exchanges, each particular discipline has its particular history which it studies, thereby producing such disciplines as the history of accounting, of anthropology, of astronomy, of biology, of chemistry, of economics, of geology, of legal studies, of mathematics, of medicine, of philosophy, of sociology, of zoology, etc. This fact naturally demands a compulsory study and reconstruction of the history of each discipline by the scientists who practise it in order to appreciate the context in which it evolved and developed, so as to understand its present circumstances and have a perspective of its future. We express the specific image the mental picture - we have of this natural and unending expansion of the influence and authority of history into the territories of other disciplines in terms of what we call 'historical imperialism in science'. Using both secondary and primary data, and arbitrarily selecting accounting, economics and philosophy from the social sciences; and astronomy, mathematics and medicine from the natural sciences for illustration, we seek to show that each particular discipline has its particular history, and so most scientists study and practise history in their respective disciplines, use historical data, and employ historical approaches, in order to understand the present position of their disciplines and to have a view of the future of their subjects. Based on the successful formulation and substantiation of the reality, authenticity and superiority of the theory of 'historical imperialism in science', we maintain that the study of history is very crucial for the survival of all disciplines, and so the significance of history at any particular point in time could be measured partly in terms of its contributions to the intellectual growth and development of all disciplines. We conclude that this realisation should be used as a justification for the serious study of history both as a separate subject in the school curriculum and as an integral part of each discipline in order to sustain the development of the disciplines, so that society could continue to benefit from their invaluable individual and collective contributions.
\end{abstract}

Keywords: discipline, historical approach, historical data, historical imperialism, historical perspectives, history, influence of history, science, the historical method, theory

\section{INTRODUCTION}

There is nothing on earth or in the heavens without its history, even the stars have their courses and sometimes disappear. Darwin, in particular looked for history in geology and earth worms before he discerned the descent or ascent of man and ... every particular science has its own particular history. The scope of history has no limit, as it embraces the entire world ... and ... all the sciences, languages and arts ... literatures ... diplomacy, music, astronomy, engineering ... geology, mineralogy, physics, economics and chemistry. Biology and anatomy ... [have their histories]. History, therefore, is the highest form of [the] sciences ... (Mohammed, 2013, July:53). 
Several scholarly anatomies of the relationship between history and other disciplines ${ }^{1}$ have been carried out by historians and other scientists. These studies often look at the exchange of ideas, experiences, methods and tools for knowledge acquisition between history and other sciences. As far as we know, no major study has been done on the natural and timeless expansion of history into the territories of other disciplines and the compulsory adoption of the historical method and the use of historical data by the practitioners ${ }^{2}$ of other disciplines in their attempts to explore and exploit their histories for the benefit of the present and the future of their sciences. The purpose of this study, therefore, is to offer a historical imperialism in science perspective of the relationship between history and other disciplines - a vision of the sciences constituting an empire with history as the emperor, or a vision of the disciplines as a federation under the control or leadership of history. As such, the major intellectual task at stake is the recovery and understanding of history as a dominant and a natural element in all sciences and, hence, an imperialist discipline, and the development of a theory of the relationship between history and other disciplines that would adequately express the nature of history as an imperialist science. This would help not only to put history in its proper position among the sciences, but also show that the usefulness of the study of history at any given time could be measured partly in terms of the significance of history to, and its imperial position in, all disciplines, irrespective of their nature.

It is important to note first that scientists guard against over-generalisation by seeking a sufficiently large sample of observations, or through the method of replication of inquiry, where a study is repeated severally to see if the same results would be produced each time. Since social phenomena could not be observed under controlled situations, the historian must accumulate more facts or evidence about the events he studies in order to be able to generalise. In view of this, the authenticity, generality and superiority of historical imperialism in science must necessarily be founded on adequate, valid, concrete and verifiable evidence. Certainly, there is enough evidence, supplied by the disciplines and the scientists who practise them, to substantiate the view that history is an imperialist discipline in the world of knowledge - in the empire of the sciences. In addition to what Mohammed (2013, July: 53) has given us above, Huxley (1953:12) has emphasised insightfully that all phenomena have a historical aspect. He considers the condensation of nebulae, the development of the infant in the womb, the formation of the Earth as a planet, and the making of a political decision all as processes in time and are, thus, historical. Leggewie (2013, July-December: 16) is, therefore, not wrong to talk of 'climate history and the history of industrialisation'. Of course, everything that exists and has a name has a past and a history. This view is what Winner (2005:75) emphasises when he maintains that football's ancientness was minted the moment the game was invented. It is absolutely in order to argue that the historical aspect, if not the entirety, of everything is usually better comprehended in a historical perspective. The tenability of these propositions implies that every serious academic discipline, whether a natural (physical) or a cultural (human or social) science, has a past and a history, and so the contemporary setting of each science could be better comprehended in,

\footnotetext{
${ }^{1}$ The English Dictionary, prepared in 2006 by Princeton University, defines the term discipline in several senses. In one, which suits our purpose, discipline means a branch of knowledge. According to the same dictionary, the term science, as is shown below, also means any branch of knowledge. In this study, therefore, we have used the two terms, discipline and science, interchangeably. However, the term science, as shown below, has been examined in detail because of the greater emphasis placed on it in this.

${ }^{2}$ A distinction has been made between the practitioner and the scientist. According to Storer (1966:14), the scientist is an individual who spends his working day in basic research and related activities: gathering information, reporting his findings, evaluating the work of other scientists, and so forth. He does this with the primary intention of extending our knowledge of some aspects of the empirical social and natural universe. Those who fit this specification are very few and include research professors in universities, those supported by industry to do basic research entirely, and those researchers who are supported by career investigatorship. Because this category of scientists are relatively few, Storer adds those he refers to as "... the immediately adjacent groups ..." of scientists who spend some of their time teaching in colleges and universities and those who are doing some applied as well as basic research in industry, government, and nonprofit organisations (p. 15). Beyond this core are those who teach but do little or no independent research. These include the strictly applied-research scientists, part-time administrators, independent consultants, technicians, and graduate students preparing to join these groups. The practitioner, on the other hand, does not actually engage in research work but rather uses the results of the scientist in his works. In other words, the practitioner applies the knowledge or findings produced by the scientist. In this study, however, we have used both terms interchangeably, although we are very much conscious of the distinctions between the two.
} 
and is, indeed, conventionally approached from, a historical point of view, drawing on the historical method and using historical data. In other words, all sciences, irrespective of their species and time of evolution, are caught up in the imperial clutches of history, inasmuch as every discipline has a history, and it is this history that has determined the present shape and nature of each science. Brako and Asah-Asante (2015:v) have argued that "... historians record events and preserve them for use by future scholars, and as such almost all academic disciplines have emerged as a result of historical recordings ...." Menger (1991:484) also observes that philosophers, jurists, economists, and even naturalists and mathematicians have dealt with history. In the real sense, therefore, most scientists study and practise some amount of history in their areas of emphasis, and all sciences humbly submit to the hegemony, rule, and dictates of history by practising history and absorbing historical approaches into their methodologies.

Rowse (1946:2-3) has argued that in the course of the nineteenth century, the methods of evolutionary science affected the study of history, but what is not so well grasped is that with the theory of evolution, history may be said to have permeated the whole conception of science. Sir Frederick Pollock (cited in Hayek, 1991:148) has also maintained that the doctrine of evolution is nothing else than the historical method applied to the facts of nature. This explains why it is often assumed that the method of investigation developed by the early historians is the precursor of the scientific method (Gorman, 1952:712). All this shows that a critical historical analysis is indispensable, in fact, a prerequisite, to a good understanding of the contemporary status of all sciences. My objective in this paper, as stated at the onset, is to formulate a theory of the relationship between history and other disciplines by showing that history pervades all fields of scientific study, all disciplines are entangled in the web of history, so that we could describe history as an imperialist science, or talk of the theory of historical imperialism in science, by which term we mean the natural extension of the influence and power of history into the territories of other disciplines and its consequent domination and administration of these fields of scientific activity through the study and practice of history by most, if not all, scientists, and their employment of the historical method of inquiry and the use of historical data, for present and future purposes. We have arbitrarily selected accounting, economics and philosophy from the social sciences; and astronomy, mathematics and medicine from the natural sciences to illustrate the substance of our argument.

\section{Methodology}

The qualitative method of research, whose focus is to find out the nature or essence of things, was used to conduct the study. Miles and Huberman (1994:10) maintain that one of the major strengths of qualitative research is that it is fundamentally well suited for locating the meanings people place on the events, processes and structures of their lives. Hence, the views, perspectives, impressions, assumption, theories, feelings, interests, etc. of people about/in phenomena do emerge in qualitative research in response to issues that influence their lives. Basically, qualitative research tends to focus on one or a small number of cases, to explore existing literature for theoretical foundations, to use intensive interviews or depth analysis of historical materials, to be discursive in method, and to be concerned with a rounded or comprehensive account of some event or unit ("The Science in Social Science" retrieved September 1, 2017). In view of this, and to achieve our objective, we relied on both primary and secondary sources of information. We began collecting data for the study first from the relevant secondary sources (see References) from which we gathered evidence of the practice of history and the application of the historical method in the various sciences. The secondary works provided us with a theoretical background which helped us to situate the work in its appropriate context. ${ }^{3}$ To authenticate the information collected from secondary works, we also collected data from primary sources (see References). The views and conclusions of both the secondary works and

\footnotetext{
${ }^{3}$ We acknowledge that we might have missed some important works which could have provided useful information to augment the literature and whose inclusion could have provided a better guide to the study, and duly apologise for any such oversights. Further, we wish to emphasise that in this study, all internet materials used have been duly cited in the text, as is usually done. However, we have provided only the surnames of the authors (where available), the full titles of the works and the dates on which we retrieved them. The website addresses are not added in the text. With regard to both personal interviews, we have provided only the surnames of the respondents, the dates on which we interviewed them, and the places where they were during the interviews. Readers are entreated to refer to the References at the end of the study for the full website addresses of all internet materials used and the full details of all interviewees.
} 
primary information helped us to put the paper in its proper perspective. We were very much aware of the limitations associated with historical documents, as with all documents in all fields of scientific study. We envisaged the likelihood of distortions of facts, exaggerations, understatements and other limitations normally associated with historical evidence. As a result, we carefully scrutinised all the data collected from the available primary and secondary sources in order to present only the accurate and reliable facts.

\section{THE THEORY OF HiSTORICAL IMPERIALISM IN SCIENCE: CONCEPTUAL FRAMEWORK}

Dewey (1959:165-166) has criticised that

The formation of historical judgments lags behind that of physical judgments not only because of greater complexity and scantiness of the data, but also because to a large extent historians have not developed the habit of stating to themselves and to the public the systematic conceptual structures which they employ in organizing their data to anything like the extent in which the physical inquirers expose their conceptual framework. Too often the conceptual framework is left as an implicit presupposition.

He emphasises that theories are as necessary to historical reconstruction as they are in inquiries in other sciences that lead to definite conclusions. A careful examination of several historical studies, be they articles in scholarly journals and magazines, chapters in books, dissertations, theses or major books of synthesis, vindicates Dewey's criticism; for some historical researchers fail to state the theoretical foundations of their works or do not outline the context in which they situate their topics or problems for analysis. In scientific research, however, the proper arrangement, classification and interpretation of the selected facts are very important, not only to enable the researcher to form and express his judgements, but also to give meaning to the facts. For this purpose, it is necessary for the data to be considered in relation to one another and synthesised into a generalisation or conclusion which places the overall significance in focus. Renier (1950:170) insists that in these operations, the researcher must be guided by his own views or theories. Essentially, every scientific research work must necessarily be situated in a specific theoretical framework, ${ }^{4}$ which provides a context in which the problem is addressed. Indeed, the problem of a study is often examined and diagnosed in a specified context. The problem of this study, as already stated, is that no serious study has been devoted to a critical examination of the nature of relationship between history, on the one hand, and other disciplines, on the other hand. The major research question we seek to address in this work, therefore, is, "What is the specific nature of the relationship between history and other sciences that makes the former significant in the lives of the latter, and what evidence do we have to prove the validity of this relationship?" The challenge here derives from the fact that so many factors are relevant in examining such a problem that it is easy to be lost, unless one has a general perspective of the subject. The vastness of the field, therefore, makes it crucial for researchers who explore the area to adopt specific conceptual or theoretical frameworks within which they situate and examine their problems or topics.

A conceptual framework is a theoretical structure of assumptions, principles and rules that holds together the ideas comprising a broad concept. It can also be defined as the system of concepts, assumptions, expectations, beliefs, and theories that supports and informs a research work. Miles and Huberman (1994:18) define a conceptual framework as a visual or written product which explains, either graphically or in narrative form, the main things to be studied; that is, the key factors, concepts, or variables, and the presumed relationships among them. Basically, the theoretical framework, or framework of interpretation, as Tosh and Lang (2006:214-215) call it, provides a lens through which the research problem is viewed, gives impetus to the inquiry, and influences its outcome. Novick (2001:1) maintains that when researchers outline for their readers the theoretical approaches they take

\footnotetext{
4 In scientific research works, the terms conceptual frameworks $(s)$, conceptual scheme(s), contextual framework(s), general law(s), generalisation(s), interpretative framework(s), perspective $(s)$, system(s), theoretical concept(s), theoretical formulation(s), theoretical framework(s), theoretical perspective $(s)$ and theory or theories are often used interchangeably to refer to the same concept. In this study, we also employ these terms at different times to refer to the same concept. However, for an explanation of these concepts and a detailed information on the application of theories in historical reconstruction, see Adjepong (2013:1-18).
} 
to the historical questions they investigate, they help to make what they have to say easier to follow and also let their readers know where they are coming from. Hence, to be able to provide the necessary direction for the study and answer the research question satisfactorily, it is crucial for us to specify the context within which we situate and address the problem. In any case, every historical analysis is a synthesis of data and interpretative framework, and so the historian must necessarily interpret his data within a specified context or conceptual framework which the available data helps him to devise (Herbst, 1962:148), meaning that every historian must invite his readers to explore his study from a particular point of view. As is clear by now, the specific inter-related variables that build the theory of historical imperialism in science are that 'every particular science has its particular history' - independent variable; and so 'most, if not all, scientists study and reconstruct the history of their disciplines, using historical data and approaches', and they do this 'in order to know the context in which their sciences evolved and developed, to understand the present position of their sciences and have a perspective of their future' - dependent variables. To be able to show how these variables are inter-related or inter-connected with one another and combine to build the theory under review, the term theory and the key concepts embodied in the theory itself - science, history and imperialism - must be explained first. Accordingly, this section outlines the conceptual framework in which we seek to answer the research question posed above, with the view to illuminating the course of the discussion. We believe that readers would better understand the substance of the study only when we clarify what we mean by these terms - theory, science, history and imperialism - to provide the needed conceptual framework that guides the study and gives it a focus.

The term theory derives from the Greek word $\theta \varepsilon \omega p i \alpha$ - theoria - literally meaning looking at, viewing, seeing, or beholding (Harrington, 2005:2; Harper, "Theory", retrieved September 9, 2010). In its original sense, theory refers to contemplation or speculation, as opposed to action. Actually, theoria is contrasted with praxis, from which the modern term practice derives; and for the ancient Greeks, praxis referred to how humans acted and conducted their lives in the immediate everyday world (Harrington, 2005:2). Harrington (Ibid.) intimates that the contemplation or reflection was on science; that is, although theoria itself did not mean science, it referred to reflection on science: reflection on the values of science, as one mode of contemplating the cosmos, among others alongside art, myth, religion and philosophy, which the ancient Greeks considered to be the most general discipline of thinking. Obviously, the ancient Greek understanding of theoria differs from how the term theory is commonly used in the modern sense. To understand theory in its appropriate contemporary context, however, it is crucial to note first that all phenomena, whether natural or cultural, have both internal and external aspects, which are considered as aspects of reality, and defined as the external and internal worlds. The internal is the spiritual world, while the external is the world of nature or the physical world, objective processes taking place in society. In another sense, they are regarded as aspects of an object or process differing by their place and role in the structure of the whole. The category of the external reflects the superficial aspect of the object immediately perceived by the senses, or the reality existing outside the object. The category of the internal stresses the essential aspect of the object. This internal aspect could not be immediately perceived; it is known only through the external, through its manifestations. The actual relationship between the external and internal dimensions is that the external aspects of the object are, by law, determined by its internal aspects, by the essence through which they are revealed and known. An investigation of the internal nature of the object leads to an understanding of its contradictions, the source of its development, and the external forms in which it manifests itself.

It follows that in practical terms, a theory may be conceived and understood from two perspectives, internal and external. At the internal level, a theory may be considered as a statement that explains or describes how the internal part of natural or cultural phenomena works or operates. To the natural sciences, for example, a theory may be defined as a well substantiated explanation of some aspect of the natural world ("Scientific Theory", retrieved September 9, 2010). It is a law of nature that purports to be nothing more than a statement of what occurs, or would happen, given certain initial conditions. In the general sense, however, a theory may be defined as an organised system of accepted knowledge that applies in a variety of situations. It may also be defined as a generalised, systematic, and economical description of the relationship that exists among a number of facts or data found within a delimited area of empirical phenomena (Storer, 1966:11). In yet another sense, a theory could be explained as a set of facts, propositions, or principles analysed in their relation to one another and used to explain phenomena in scientific studies. In simple terms, however, a theory is an organised set 
of principles that is designed to explain and predict the relationship existing between some facts (Storer, 1966:11). At the external level, a theory may be defined as an image, a picture or a representation of reality. Hawking (1989:10), for example, maintains that since a theory is just a model of the universe, or a restricted part of it, and a set of rules that relate quantities in the model to observations that researchers make, a theory exists only in our mind and does not have any other reality. In this sense, a theory is a mental picture, or idealisation, founded on physical concepts and aesthetic notions that accounts for what scientists see regarding a particular phenomenon (Evans, "Theories in Science", retrieved September 9, 2010). Thus, a well-formulated theory should provide an ideal picture of how and why a general process works; it must provide a way to conceptualising the process by reducing it to simple relationships (Fields, Barber and Riggs, 1988:17). Consequently, as with any picture, the creator decides which elements are important and how they fit together, and to make it simple enough to be easily comprehended, minor elements may be omitted. The result draws our attention to inter-connections or relationships that are central and critical, stripping away features or details that disguise what the creator of the theory sees as the general pattern.

Theories may be expressed mathematically, symbolically, or in words, but are generally expected to follow principles of rational thought or logic. These modes of expression indicate that theories are of different types and categories. Generally, theories may be put into two broad categories, namely philosophical and scientific. Scientific theories are explanations of phenomena which meet basic requirements about the kinds of empirical observations made, the methods of classification used, and the consistency of the theories in their application among members of the classes to which they pertain. These requirements vary from one scientific field of knowledge to another, but in general, scientific theories are expected to be functional and economical, and to be accurate, predictive descriptions or explanations of the natural and cultural worlds. On the other hand, theories whose subject-matter consists not in empirical data, but rather in ideas are in the realm of philosophical theories. The reason is that the variables of philosophical theories are usually statements whose truth could not necessarily be scientifically tested through empirical observation. The theory we seek to formulate - historical imperialism in science - falls under the philosophical category in the sense that it does not consist in empirical data and, for that matter, could not be tested in controlled situations or through laboratory experiments. Rather, it consists in ideas, and so its factuality, validity and superiority could be tested mainly through observation, interpretation and comparison, which, as Beattie (1977:78) emphasises, constitute the tools that are usually employed by social scientists in testing their hypotheses.

The term science, according to The Wordsworth Dictionary of Phrase \& Fable, derives from the Latin term scienta, which, in turn, evolved from scire, meaning to know. In the literal sense, therefore, science means knowledge (Evans, 1993:969). In spite of its original meaning, science has been severally defined for different purposes and under different circumstances. For this reason, E.M.A. Ukoli (cited in Gabriel, Fagbenle and Jaja, 1998:2) has recognised the difficulty of providing a specific meaning for science. In line with its literal interpretation, however, science has been viewed primarily as a source of knowledge, producing new information about the empirical universe to the larger society (Storer, 1966:1). Harré (1972:62) defines science as “... a collection of well-attested theories which explain the patterns and regularities and irregularities among carefully studied phenomena." Supporting Harré's view, and being more specific, The Wordsworth Dictionary of Science and Technology states that "Speculative science is that branch of science which suggests hypotheses and theories, and deduces critical tests whereby uncoordinated observations and properly ascertained facts may be brought into the body of science proper" (Walker, 1995:789). Clearly, these definitions appear to make science synonymous with theory. At any rate, theories are the vehicles of natural scientific knowledge - the foundations of their efficacy - and that is why a natural scientist like Krogh (1996:7) maintains that when science is conceived as a body of knowledge, it refers to a collection of unified insights, commonly referred to as theories, about nature, the evidence for which is an array of facts. In some quarters, however, science has been perceived rather as the systematic accumulation of knowledge about, or study of, natural or physical phenomena. Gabriel, Fagbenle and Jaja (1998:2), for instance, show that science has been defined elsewhere as the study of nature and its physical environment, especially by using systematic and direct observation and experiment. Sir Alister Hardy (cited in Matson, 1975:114) has also asserted "that which is truly scientific will ultimately be explained in terms of physics and chemistry." 
The description of science as the study of something and the recognition that the search for knowledge and the truth is basic to the study of science (Gabriel, Fagbenle and Jaja, 1998:3) indicate the appreciation of science as a body of knowledge. The English Dictionary, for example, defines science as any branch or department of systematised knowledge considered as a distinct field of investigation or object of study (Princeton University, 2006). The problem here, however, is that these definitions create the impression that science itself, as well as the systematic acquisition of knowledge in general, is an exclusive preserve of the natural or physical sciences; but, this is not true. Harrington (2005:3), for example, admits that science has close connections with the natural sciences and is often used synonymously with them, but argues that these sciences are not the only disciplines of human inquiry with a claim to the title of science. There are even some natural scientists who disapprove of restricting the term science to refer, for example, to "coloured liquid in a glass tube", or to "the paraphernalia of the physics laboratory", or "a terminology liberally interspersed with mathematical formula" (Kumekpor, 1999:5). On such misleading interpretations of science, Lundberg (1949:1) remarks that the idea of science as a particular method of study, a definite set of rules of procedure and of logic applicable to any subject-matter has been neglected in our preoccupation with the amazing findings and achievements of the natural sciences. To him, the term science should be used to designate method, while occasionally applying it to any body of knowledge arrived at by this method. As a result, he defines science as a technique of deriving reliable knowledge about any type of phenomena in the universe and then applying this derived knowledge for purposes of prediction and control (Ibid.). Krogh (1996:7) also perceives science, in another sense, as a process, a way of learning, an activity that is the object of careful study or that is carried out according to a developed method or “... under certain loosely agreed-to rules.” Frederick J. Teggard (cited Kumekpor, 1999:6) even stresses that at present, the method of science has come to stand for branches of inquiring knowledge, characterised by specific aims and modes of procedure. To The Wordsworth Dictionary of Science and Technology, science is "... the ordered arrangement of ascertained knowledge, including the methods by which such knowledge is extended and the criteria by which its truth is tested" (Walker, 1995:789). And in Harrington's (2005:3) view, to think scientifically is to apply a method or methods to the study of something and to follow these methods consistently and transparently. Evidently, science is now taken from the stage of being considered only as a body of knowledge to that of being considered also as a method by which this particular body of knowledge is ascertained and interpreted. On this new and broad plane, it is usually required that in order to be scientific, the method must be reliable and aim at securing the principle of accuracy (Kumekpor, 1999:5-6).

From the different definitions of science examined here, certain cardinal principles are obvious. We have, first, the literal meaning of science as knowledge, from which 'science as a body of knowledge' derives. This conception, in turn, produces another definition of science, as a systematic procedure or method for the acquisition of knowledge in order to address existing problems. Giner (1972:15) even emphasises that the original Latin notion of scienta has now come to mean objective and rational knowledge of reality or, more strictly, consistent effort towards the possession of such knowledge. Taking all this into consideration, we conceive of science as an organised body, or a special field, of knowledge which, constructively and critically, employs an accepted standard procedure or method in analysing processes or problems - of academic, technical, vocational, etc. nature - with the view to producing scientific results or solutions to address problems. Generally, when we talk of science as a body of knowledge, we often mean individual or special branches of knowledge dedicated to the acquisition of knowledge about specific subject-matter. It follows, then, that any subject or discipline that employs scientific methods in the pursuit of knowledge is a science. ${ }^{5}$ As Gabriel, Fagbenle and Jaja (1998:2) have rightly pointed out, “... the scientific method is not the exclusive preserve of the [natural] scientist because other disciplines and professionals like psychologists, historians, sociologists, detectives, and lawyers adopt this approach." On his part, Harrington (2005:3) boldly states that in the real sense, astronomy, biology, chemistry or physics are not the only disciplines of inquiry with a claim to being sciences. "Other subjects of study, such as history, archaeology, or art criticism can also be sciences." He justifies his claim by showing that in French, the subjects known in English as the humanities are called les sciences humaines, while in German they are known as the Geisteswissenschafen, meaning science of the mind or sciences of the works of the human mind (Ibid.,

\footnotetext{
${ }^{5}$ These arguments defeat the view that the degree to which a discipline is truly scientific depends on the degree to which it can be made mathematical. See Palmer and Colton, 1964:264.
} 
p. 4). In effect, every discipline is a science in its own right since each discipline constitutes a separate and a special body of knowledge, and employs the scientific method in the pursuit of knowledge and the truth. In this case, each branch of knowledge constitutes a part or subset of the whole body of science.

It is necessary to state that because there are different categories and levels of knowledge, each science is concerned with a specific area of emphasis or subject-matter, and this specific focus gives each science a unique identity in the kingdom of the sciences, as the specific concerns make each of them adopt certain unique or different set of criteria, methods and features that lies outside or beyond the interest and methodological reach of other sciences. Harrington (2005:4), for instance, stresses that a scientific way of proceeding in biochemistry is significantly different from a scientific way of proceeding in a subject like art criticism. This underscores the differences between and among the sciences which allow nomenclature into subgroups. Generally, the sciences have been grouped into two kinds - those which study nature (the natural or physical sciences) and those which study humans and society (the cultural, human or social sciences). ${ }^{6}$ Each of the natural sciences focuses on part of the total natural environment, whereas each of the human sciences deals with an aspect of the entire social experience. Each sees phenomena from a particular perspective, but each, when well done, adds its own contribution to the total record of natural and social experience.

In view of this division of labour, it is improper to argue that any one particular science or group of sciences is inherently better than, and superior to, other sciences. Some are perhaps more generally useful, that is, more interesting to a wider segment of the public or readership, or more suggestive at a particular time and place than others, but the distinctions are like those between a miniature and a mural, a sonnet and an epic poem. ${ }^{7}$ As Giner (1972:10) has argued, the distinctions between the sciences are convenient but not really substantial, because the methods and results of each science are necessary to the others: there is a constant and natural osmosis between them. Even the so-called specific areas of emphasis are not significant in the case of some sciences. Gorman (1952:89), for example, argues that astronomy has connections with biology, mathematics, physics and psychology. Moreover, because of the nature of some of their activities, some of the social sciences are sometimes even given natural science status. Giner (1972:15), for instance, intimates that when sociology attempts to understand the meaning of social life in each instance studied, it is one of the human sciences, but when it attempts to disclose objective causal relations, correlations, and regularities, it is one of the natural sciences. It is interesting to note also that in terms of philosophical premise, there is, in point of fact, no difference between the sciences; for they were all born of a pathetic desire to help humans escape from the uncertainties of life, of a passionate longing to endow our contradictory world with meaning, and of a quest for certainty (Renier, 1950:145). That is why Magee (1973:17) posits that ideas originally worked out in the natural sciences have been extended to the social sciences, and that it is necessary to show how the two are parts of a single philosophy which embraces both the natural and the human worlds. Again, it is essential to note that the natural sciences equally have an $\mathrm{art}^{8}$ dimension, because natural scientists sometimes resort to subjective judgment where

\footnotetext{
${ }^{6}$ Note, however, that some scholars divide the sciences into three categories, according to their methodologies and purposes. These are the analytical, normative and humanities (Gemtou, 2011:641). It is asserted that the analytical sciences aim at objective truth and an explanation of the world. They apply a nomological approach in order to include their results in a framework of laws and regularities. To the analytical sciences belong the natural (e.g. physics, chemistry, medicine) and social (e.g. economics, sociology) sciences, which have an empirical character, and also mathematics and logic, which provide formal tools. The normative sciences are those disciplines which research ways of regulating the world. They are said to apply a regulative-deontological approach and their methodology is based on principles that imply criteria of right or wrong. The most significant examples of the normative sciences are jurisprudence and ethics. The humanities are those sciences which aim at the interpretation and understanding of human actions and intellectual works by drawing their basic methodological tools from the hermeneutical tradition and rely on their central analytic category, which is comprehension, that seeks to ascribe meaning, in a kind of subjective transfer, to the spirit of these actions, or to works of art. The humanities are value-oriented, and to them belong such sciences as, among others, philology, art history and theatre studies (Ibid.).

${ }^{7}$ Hughes (2001:6) has argued that the distinction, first made by the ancient Greeks, between nature and culture is not an absolute one because in an important sense, culture is part of nature in the sense that culture is the product of a species of animal, the human species.

${ }^{8}$ For instance, medicine is often perceived more as an art than a science, because of the wider scope of the relationship between the doctor and the patient, which is not consistent with strict scientific limitations.
} 
mere intuition, feelings and taste come to play (Gabriel, Fagbenle and Jaja, 1998:3). Porter (1994:vii) has also posited that natural science is not always impersonal: a method, a system, a technique for generating knowledge; it is also highly personal because of the involvement of the individuals who have discovered its truths. Similarly, Einstein (cited in Knight, 1996:xi) is reported to have described natural science as being a free creation of the human mind, while Knight (Ibid.) also asserts that natural science is a fully human activity.

Fundamentally, if science is defined as a systematically organized body of knowledge about a particular discipline, and as an activity that is the object of careful study or that is carried out according to a developed method, then history, like any other discipline, is a science. Again, if the scientific method implies the attempt to understand and explain logically and objectively a specific area of reality, and if the scientific method involves the systematic posing and testing of hypotheses, then history is a science. In fact, history originally means research or any learning or knowing achieved through a vigorous and critical inquiry (Cohen and Nagel, 1934:323), and implies the act of judging the evidence in order to separate fact from fiction. In the acquisition of historical information, historians employ techniques which are generally referred to as the critical or historical method. The historical method is scientific in the sense that its rules are subject to verification. By this method, professional historians employ techniques that allow them to carefully sift, test, collate and evaluate historical documents, in addition to the use of the most vigorous methods in judging the objectivity, impartiality, and accuracy of historical works, in order to arrive at accurate conclusions. The trained historian is, thus, no less systematic, exact and critical in his research than the chemist or the biologist. For instance, the anthropologist, E.E. Evans-Pritchard (cited in Marwick, 1993:156), sounding as if disturbed, has queried:

When will people get it into their heads that the conscientious historian ... is no less systematic, exacting and critical in his research than a chemist or biologist, that it is not in method that ... [historical] science differs from physical science but in the nature of the phenomena they study.

Renier (1950:245) has also maintained that there is no difference between the natural scientist and the historian in terms of the application of the scientific method in the sense that

... history ... is a discipline which approaches its subject-matter in the same scientific spirit as [the natural] science[s]. It has the same way of looking upon the gradual acquisition of accurate knowledge; like [physical] science, it seeks knowledge for the sake of action, and tests the value of its knowledge in the process of acting.

The American diplomatic historian, Schmitt (1960:23), has added that if science is defined as a

... 'systematised, organised, formulated knowledge', ... [then] history, the original meaning of which is investigation, is ... a science if it is pursued with the sole aim of ascertaining the truth, if all relevant facts are diligently searched for, if presuppositions and prejudices are eliminated, if the constants and the variables are noted and plotted with the same care that is the rule in the natural sciences.

Meanwhile, both Johann Gustav Droysen and Ernest Renan (cited in "Historical Quotes", retrieved July 29,2012 ) have maintained that history is the only discipline which enjoys the ambiguous fortune of being both a science and an art at the same time. Lynn Thorndike (cited in Barzun and Graff, 1977:44) has also emphasised that

... for some, history is literature; for others, facts; for some, delving in archives; for others, interpretations of the sources; for some, an art; for others, a science; for some, drudgery; for others, a romance; for some, an explanation of the present; [and] for others a revelation and a realization of the past.

Moreover, medical practice is linked to moral evaluations, as doctors are required to provide services to all people regardless of social and other criteria (see Gemtou, 2011:640). 
It is obvious that however history is defined, the discipline has both art and science dimensions. Taking all this into cognisance, we have chosen to define history as the science, art and practice of studying, interpreting and giving meaning to significant past human activities and events, through the application of the critical or historical method of inquiry, with the view to understanding the present and having a perspective of the future. ${ }^{9}$ This definition is premised on the fact that developments of the past impact on present events, and these effects, which the present drags along with it, together with those of present occurrences, impact on the future by means of inheritance. In fact, it has to be appreciated that although the subject-matter of history belongs mostly to the past, in reality, and for practical purposes, the focus of history is on the present and the future, meaning that history is concerned with the three divisions of time: the past, the present and the future. This means that a good reconstruction of the past affords an understanding of the present and a perspective of the future. This is the basis of M.D. Suleiman's definition of history as being all about activities of humans in time perspective - what was done, being done and would be done (Mohammed, 2013, July:50). Note also that the historical method, as already stated, is a process supplementary to observations, a process by which the historian attempts to test the truthfulness of the reports of observations made by others (Hockett, 1961:8). Thus defined, history and the historical method seem to unify the sciences or appear to make all sciences historical in view of their common possession of history and, thus, the study of their respective histories, and the adoption of the historical method of inquiry in this pursuit. Genuinely, a critical observation of the sciences indicates first that history is a natural and a fundamental element in all sciences inasmuch as every science has a history which is as old as the discipline itself, because each science starts accumulating history from the very day it is invented or born. In the deeper sense, however, this observation shows that the relationship between history and the other sciences could be conceived of and understood better in the context of the theory of imperialism. Even the fact that history depends more on the methods, tools, achievements and experiences of other sciences could not in any way change the nature of this relationship, when we consider these parasitic advantages as some of the benefits of imperialism. ${ }^{10}$

Curtin (1971:ix) has asserted that imperialism is a word of many meanings, whereas Schumpeter (1951:5) has complained that the term imperialism has been abused as a slogan to the point where it threatens to lose all meaning. The cause of this problem is that, historically, the term imperialism has been used in different contexts and has, thus, meant different things to different peoples at different times. It is, however, acknowledged that imperialism is related to the term imperial which derives from the Latin word imperialis (from imperium), meaning command or pertaining to an emperor or empire (Safra and Yeshua (2003:273). ${ }^{11}$ There are some basic characteristics of imperialism and basic principles of imperial policy that enable scholars to agree on the essential nature of the concept. Schumpeter (1951:6) defines imperialism simply as the general disposition on the part of a state to unlimited forcible expansion. Lake (2001:7232) posits that as an analytic concept, imperialism refers to the effective domination of one political community by another. Smith and Zurcher (1955:192) also explain imperialism as the official policy of extending the sovereignty or dominion of a state, especially the acquisition of territory outside its natural boundaries which is inhabited by other peoples. To Safra and Yeshua (2003:272), imperialism is a state policy, practice, or advocacy of extending powers and dominion, especially by direct territorial acquisition or by gaining political and economic control of other areas. Allied to this definition is the view that imperialism is a policy in which one country seeks to extend its authority by conquering other countries or by establishing economic and political dominance over other countries ("Imperialism - Case Study: Nigeria", p. 780, retrieved August 5, 2017). In general terms, however, imperialism refers, more broadly, to control or influence that is exercised either formally or informally, directly or indirectly, politically or economically.

From the various definitions, we wish to employ imperialism in this paper to refer to a situation whereby a more powerful state extends its influence beyond its borders and exercises power in the

\footnotetext{
${ }^{9}$ Readers may also refer to Adjepong (2014:1-16) for a detailed study of some of the major definitions or interpretations of history.

${ }^{10}$ See the conclusion for some of the costs and benefits of imperialism.

11 Although imperialism is an ancient phenomenon, Gay and Webb (1973:840) insists that it first arose in the France of Louis-Philippe and was later foisted on Napoleon III to signify his high-handed dictatorship, and, hence, began as a term for the display of domestic power.
} 
territories of other states, dominates the political, economic, and social lives of those states, and, consequently, has the ability to decide policy for the subordinate states, and this ability may entail substantial delegation of decision-making authority to elite members of the colony. Defined this way, imperialism helps highlight the relationship between history, on the one hand, and all other sciences, on the other hand, considering that imperialism usually establishes relationships between states. Lake (2001:7232), for example, argues that imperialism is a form of international hierarchy and one of the oldest known political institutions, characterising relations between peoples. Michael Doyle (cited in Ibid.) also maintains that imperialism leads to the establishment of relationships of political control imposed by some political societies over the effective sovereignty of other political societies. Again, Kemp (1972:18) intimates that for many people, imperialism generally means principally or exclusively the relationship between advanced, imperial countries and colonial or semi-colonial areas falling within their formal or informal empires.

Meanwhile, for practical purposes, the specific nature of the relationship - or what we have described as historical imperialism in science - must be clarified. Note first that there are different forms of control. In colonial relationships (colonies), the peoples and resources of the colonial territories are totally subjected to the power, authority and control of the imperialist powers whose colonial agents ensure the effective implementation of colonial policies designed by the powers to ensure that the human and material resources of the colonies primarily serve the interest of the imperialist powers (Osabu-Kle, "African Blood for Imperialist Interests: The First and Second Scrambles for Africa", retrieved August 5, 2017). In territories commonly referred to as spheres-of-influence, the subordinate members remain independent but are constrained by the dominant powers from forming relationships such as alliances with other great powers. Latin America under the Monroe Doctrine, ${ }^{12}$ according to Lake (2001:7232), and Liberia under the sphere of influence of the United States are classic examples. In protectorates, subordinate states remain independent, but they yield control over specific areas of policy, especially their foreign and defence policies, to the dominant or controlling powers. ${ }^{13}$ In what is described as informal empires, subordinates are subject to imperial states across wide ranges of policy but retain their international personalities and interact with third parties on the basis of sovereign equality, with Eastern Europe under the Soviet Union being a particularly clear example (Ibid.).

Without doubt, every science has a history which its practitioners explore and exploit for their present understanding and use, and in this practice, scientists are compelled to employ the historical method of inquiry. In other words, most scientists do historical research which is concerned with the past and which attempts to trace the past as a means of seeing the present in prospective. In this context, there is a form of control of history over other sciences; there are some dictates or orders from history to other disciplines, which establish a sort of overlord-vassals or master-subjects relationship between history and other sciences. However, every science enjoys a greater amount of autonomy in its own territory; each discipline is sovereign and focuses on a specific subject-matter. As a result, we should not expect any science to remain only as a submissive colony or an extremely humble sphere-ofinfluence to history and, thus, transfer control of all its undertakings and relations with other sciences to history, and do pure historical studies; neither should we expect them to employ only the historical method of inquiry, especially as their specific focus and activities, and foreign relations would naturally determine the invention of new and special techniques of inquiry. In view of all this, we would describe the other sciences as protectorates and informal empires in relation to history. Even when we consider them as colonies, we do so in the case of territories where the policy of indirect rule is implemented, so that there is some form or amount of local autonomy, and the maintenance of

\footnotetext{
12 The Monroe Doctrine, which declared USA resistance to European intervention in the Western Hemisphere, was inserted into President Monroe's 1823 State of the Union report written by Secretary of State John Quincy Adams (see Davidson and Oleszek, 2004:392).

13 A colony refers to a territory or a country under a full or partial political control of another country and occupied by settlers from that country. A colony may also be explained as a stretch of land that has fallen under the administration of foreigners. In other words, a colony is a territory that is administered by people from a foreign land

(Brako and Asah-Asante, 2015:24). A protectorate is a country or a territory with its own internal government but under the control of an outside power; a sphere-of-influence is an area in which an outside power claims exclusive investment or trading privileges "Imperialism - Case Study: Nigeria", p. 780, retrieved August 5, 2017).
} 
indigenous social, economic and political institutions and structures that are essential for the development of the colonial territories.

It is important to note, however, that irrespective of how they are described and the form of control over them, colonies, spheres-of-influence, protectorates and informal empires are all forms of imperialism. Thus, no matter the nature and extent of authority history has over other sciences, the relationship still remains one of overlord-vassals, which is borne out by the activities and approaches of the practitioners of other sciences themselves. They often do this by prefacing their studies with historical analysis, where they usually examine the historical development of their sciences and assess the historical background or antecedents of some of the topics or problems they handle. In doing this, they adopt a perspective (prospective) or a retrospective approach, the two main approaches of historical research and, for that matter, call for a scholarly search for historical data. Clearly, both social and natural scientists practise history in appreciation of the fact that history is a background for all sciences. Below, we have categorised the sciences into social and natural, and arbitrarily selected some of the sciences under the categories to show the practice of history in those disciplines and the adoption and use of the historical method and historical data respectively as evidence to illustrate the arguments of the paper.

\section{HiSTORICAL IMPERIALISM IN THE SOCIAL SCIENCES}

With the social sciences, we set out by confidently asserting that none of them is ahistorical; none could ever claim to be unconcerned with or unrelated to history or to historical developments. Because of the generality and superiority of the theory of historical imperialism in the social sciences, Foucault (1970:405) maintains that

History constitutes ... for the human sciences, a favourable environment .... To each of the sciences of man it offers a background, which establishes it and provides it with a fixed ground and, as it were, a homeland; it determines the cultural area - the chronological and geographical boundaries - in which that branch of knowledge can be recognized as having validity .... Even when they avoid all reference to history, the human sciences ... never do anything but relate one cultural episode to another (that to which they apply themselves as their object, and that in which their existence, their mode of being, their methods, and their concepts have their roots); and though they apply themselves to their own synchronology, they relate the cultural episode from which they emerged to itself.

Wilhelm Dilthey (1833-1911) has also argued that the study of the human or social sciences involves the interaction of personal experience; the reflective understanding of experience; and an expression of the spirit in gesture, words, and, therefore, argues that not only the social sciences but all learning must be seen in the light of history; otherwise, knowledge and understanding could be only partial. C. Wright Mills (cited in Szasz, "Historical Quotations", retrieved June 7, 2013) asserts that every social science or every well-considered social study requires a historical scope of conception and a full use of historical materials. Mills makes this observation because he believes that history is the shank of the social sciences. Conal Furay and Michael J. Salevouris (cited in Maxwell, "The Uses of History: Why Bother with History?", retrieved May 16, 2012) have also noted that historical knowledge is extremely valuable in the pursuit of other disciplines, such as literature, art, religion, political science, sociology, and economics. In the same way, Vives (cited in Aggarwal, 2004:28) has remarked that moral philosophy is built upon history, the whole of law flows out of history, and a great part of theology is history. Gay and Webb (1973:624) also talk of the historical study of jurisprudence and political economy in German universities at the beginning of the nineteenth century. In fact, in 1916, scholars found it necessary to carry out a critical inquiry into the relation of history to literature, philosophy and natural science and, in 1925, even extended the application of the historical method to more areas of humanistic interest (Teggart, 1960:v). It was appreciated that there was the need for a knowledge of a sort which could be derived only from an exacting inquiry into the actualities of human experience; it was also recognised that the materials required for such a study were available in historical documents, while social scientists also employed historical data to provide factual illustrations for a priori theories of progress, evolution and stages of development (Ibid., pp. v-vi). 
Many practitioners of the social sciences affirm the authenticity of the theory of historical imperialism in science in their disciplines. For example, Ebeling (1991:xiii) severally reminds his readers of the reality of 'the history of economic thought'. Again, the fact that ethnology classifies peoples in terms of their racial and cultural characteristics, and attempts to explain these by reference to their history or pre-history (Beattie, 1977:19), and Beattie's confession that when he was carrying out a field study in the kingdom of Bunyoro, in western Uganda, he was interested, among others, in contemporary Nyoro-European relations, but without some knowledge of the history of Western contacts with Bunyoro these would have been quite inexplicable (Ibid., p. 23), underscore the fact that answering some questions in anthropological studies requires a historical approach to contemporary issues. Also, in spite of the assumed distinctions between history and sociology, as idiographic and nomothetic sciences respectively, it has been emphasised that the study of basic data concerning, among others, history is considered an important preliminary before undertaken a sociological research into a society. The priceless contribution of history to sociological study has even led to the development of a special branch of sociology called historical sociology, which concerns itself with how societies develop through history. Sociologists' belief that events that happened in the past have some or a lot of influence on events that happen in the present, a process they describe as pathdependency or path-dependence, underpins their explanations of present arrangements, that is, institutions, cultural forms, etc., as the cumulative and selectively reproduced products of past social actions, which, in turn, provide the basis for future endeavours and aspirations. With this philosophy, Walker and Katz (2002:23), for instance, examine contemporary American policing by first tracing the origins of the American police to as far back as old England, through colonial America, to the modern era, believing that the American police itself, and many basic police practices, procedures, and problems are rooted in the past.

In their attempts to help formulate laws for the regulation of society, lawyers also usually consult historical documents for historical facts and make inferences from historical developments. For example, in helping to develop coherent, legitimate and viable constitutional criteria for assessing constitutional practice in Ghana, Tsikata (1991:211-219) goes back into the history of Ghana and the history of the development of bourgeois democracy in Western Europe to identify important strands in the relevant historical experience which bear upon both the assessment of constitutional practice, and the formulation of constitutional goals and institutions. He adopts the historical approach with the conviction that the present constitutional practices and institutions of every society have been part of the evolutionary process through the historical experiences of these societies. The American philosopher James (1971:18-19) has also described literature as little more than an appreciative chronicle of human master-strokes, so far as it takes the form of criticism and history. All this helps us to better appreciate the essence of the study of history, the adoption of the historical method or approach and the consequent use of historical data in the social sciences. Among these sciences, accounting, economics, and philosophy have been selected for elaborate emphasis and illustration.

\section{Accounting}

Accounting as it is practiced today, evolved gradually over the years, and we must pin-point the time of the first Accounting system. ... The reason behind accounting history is to appreciate some pattern of development in the field of study (Akinyemi, Okoye and Izedoumi, 2015:14).

Accounting is usually defined as the process of recording, classifying, analysing, summarising and reporting, in a significant manner and in monetary terms, business transactions and events to meet users' needs (Bosu: personal interview, August 24, 2017; Marfo-Yiadom, Asante and Tackie, 2012:2). In this sense, accounting may appear to some people to have nothing to do at all with history, in spite of the fact that the discipline has a worthy past. This may probably be due to the fact that the main purpose of accounting is to provide quantitative information expressed in terms of money to users to make economic decisions. Yet, experts in accounting often acknowledge the importance of history to a good understanding of the present state of their discipline. In their Introduction to Financial Accounting \& Reporting, Marfo-Yiadom, Asante and Tackie (2012:2) have created a special section, entitled "Evolution of Accounting", in the first chapter of the study under the broad heading "Meaning and Scope of Accounting." These authors examine the evolution and development of accounting by stating first that by 8500 B.C.E., accounting already existed. They show the nature of accounting in the B.C.E. era by emphasising that clay tokens, later to be replaced by wet clay tablets, 
were used in the Middle East in keeping records. They mention the Pharaohs of ancient Egypt as examples of past leaders who used accounting to keep track of labour and material costs used in building magnificent structures such as the pyramids. In the C.E. or modern period, they stress that there was advancement in account keeping methods in trade from the thirteenth to the fifteenth centuries. They also indicate the coming in for the first time of double entry records in C.E. 1340 in Genoa, Italy, and the formulation of the first systematic record keeping by Fra Luca Pacioli, a celebrated mathematician who is considered as the Father of Accounting (Ibid., p. 3). They emphasise the development of cost accounting as a special field of accounting during the period of the Industrial Revolution. They end their discussion with the assertion that today, accounting has moved towards the information age, and that an emerging trend in accounting is the gradual shift from mechanical accounting to financial reporting.

Dr. Leticia Bosu (personal interview: August 24, 2017), an accounting lecturer at University of Cape Coast, reveals that she also always begins her lectures with "Evolution of Accounting". She intimates that Pacioli did not actually invent accounting. She admits, however, that the first accounting book was one of five sections in Pacioli's mathematics book, Everything about Arithmetic, Geometry, and Proportions, and that this section served as the world's only accounting textbook well into the sixteenth century. In acknowledging the importance of the study of the history of accounting, she stresses that accounting practitioners in public accounting, industry, and non-profit organisations, as well as investors, lending institutions, business firms, and all other users of financial information are highly indebted to Pacioli for his monumental role in the development of accounting. The most important point she makes is that without a knowledge of the history of accounting, it would be difficult for practitioners and students of accounting today to understand how accounting came to assume its present position.

In much the same way, all branches of accounting, including financial accounting, management accounting, auditing, taxation and financial management, also have histories which are duly studied and taught in the respective fields. For example, in an interview with the author, Awuku (personal interview: August 22, 2017, University of Cape Coast campus), an accounting graduate, emphasised the study of several historical developments in financial management, including how the Modiligan and Morgan model overthrew existing traditional models of cost of capital, when he was in the final year at the university. Akakpo (2013) also devotes the first chapter of his Principles, Concepts and Practice of Taxation to a detailed examination of the history of taxation. He begins his introduction with the statement, "Tax is said to date back to biblical times where subjects or citizens were made to pay tax in time and in wealth towards the building of [the] Babel tower and [the] Jerusalem Temple" (pp. 1 and 2). After making this statement, he divides his historical analysis of taxation into three main sections, "Taxation in Roman Times", "The Introduction of Taxation in the UK", and "Historical and Legal Framework of Taxation in Ghana" (Ibid., pp. 2-10). The number of pages (10 pages) Akakpo devotes to the historical treatment of taxation is, without doubt, an indication of how important the history of taxation is to him. In his Taxation in Ghana: Principles, Practice and Planning, Abdallah (2006) equally begins his study with a historical appraisal of taxation. In the introduction to the first chapter, he informs his readers that taxation was introduced in Ghana by the British colonial administration in 1943 (Income Tax Ordinance (No. 27), 1943). He states, however, that “ $\ldots$ before the introduction of income tax in 1943, several attempts had already been made, for example, as far back as April 1852, the Poll Tax Ordinance was passed to raise money to finance the increased cost of British Administration" (p. 3). This shows that Abdallah prefaces his work with a historical analysis of taxation from 1852 to 2000 in order to give his readers an understanding of how taxation in Ghana evolved and got to where it is now.

Even some concepts in accounting enjoin accountants to appreciate the past and are, therefore, indicators of how significant history is to accounting. Typical examples of these concepts are assets, liabilities and historical cost convention or the principle of historical cost. Historical cost convention, for instance, asserts that assets should be shown on the statement of financial position (balance sheet) at their original cost, the amount which the business paid to acquire them, rather than at some assessment of current value (Bosu: personal interview, August 24, 2017, Cape Coast; Marfo-Yiadom, Asante and Tackie, 2012:18). In other words, the principle of historical cost requires all financial statement items to be based on original cost (Jain, 2010:273). In this case, the cost of an asset purchased thirty years ago for say $\mathrm{GH} \phi 15,000.00$ is disclosed in the accounts book as $\mathrm{GH} \phi 15,000.00$ 
which was the cost of its original purchase. Depreciation is calculated using the original cost as the basis. Similarly, a sale of $\mathrm{GH} \not 1,000.00$ on September 17, 2016 is recorded exactly as $\mathrm{GH} \phi 1,000.00$ in the book of accounts. At the end of the financial year, it is aggregated with other sales in the year, but the value given to it remains the same value of $\mathrm{GH} \phi 1,000.00 .{ }^{14}$ Accordingly, accountants and auditors strictly prepare financial statements of business firms and other institutions using the historical cost convention. For instance, the University of Cape Coast (2011:9) and Assinman Rural Bank Limited (2012:17) have shown in their financial statements that the preparation was done under the historical cost convention. The Nestle Group (2012, February 15:52 and 143) also prepared the "Consolidated Financial Statements of the Nestle Group 2011" and the "145th Financial Statements of Nestle S.A." strictly "... in accordance with accounting principles required ... under the historical cost convention and on the accruals basis." The fact that financial statements are prepared under the historical cost convention implies that these statements are essentially records of past transactions. A land purchased in the past may worth a higher value in the present, yet this current value should not be reflected in the accounts.

That some professional accountants appreciate and examine the history of their science, and that some accounting concepts charge accountants to appreciate their past records are clear. What is not certain is the reason why accountants should be concerned with their past. The answer is that they explore their history primarily to understand their present and be able to forecast their future. For instance, Marfo-Yiadom, Asante and Tackie could come to the conclusion that the nature of accounting has been shifting from one emphasis to another and that there is an emerging trend in the discipline only after having examined the history of the discipline. In other words, it is their knowledge of the past that has enabled them to understand the current state of accounting. In their paper, "History and Development of Accounting in Perspective", Akinyemi, Okoye and Izedoumi (2015:15) stress that "The study of accounting history helps us to understand our past, and gives us an appreciation of how our current practices and problems came into being." To emphasise their point, they add,

The historical concept of accounting provides clues and explanations for most of the important events that shape the development of modern accounting. The history and development of Accounting will be useful to accounting users, providers, certifiers, trainees, trainers, and accounting professional bodies in reflecting whether they have played a major role in accounting development (p. 20).

Also, the historical cost convention concept is usually supported on the grounds that it provides an objective, reliable base for financial reporting than the use of figures based on estimates of current value. Outlay (historic) cost can be determined by reference to fact rather than opinion; hence, the figures produced are free from bias and capable of independent verification. The main advantage of this concept is that the objectivity of accounts is maximised, for there is usually an objective written evidence to prove the amount paid to purchase an asset or pay an expense (Marfo-Yiadom, Asante and Tackie, 2012:18). Jain (2010:273) also maintains that in accounting (and banking), historical data refer to past information about a company, including historical price, price/earnings ratio, revenues and revenue growth, and earnings and earnings growth, and this information is used to help forecast the company's future. Obviously, the study of history is important to accountants because of its potential in helping them to understand the present and have a view of the future. What accounting practitioners themselves have said here is, of course, a clear admission of historical imperialism in accounting.

\section{Economics}

... every economic experience is historical in the sense that it is the experience of something past .... It is ... economic theory which makes it possible for us to conceive the economic facts of the past (Mises, 1991:103).

\footnotetext{
${ }^{14}$ Other equally significant historical concepts which emphasise the importance of history to accounting (and banking) include historical data, historical trading range and historical yield. Because of its importance to the analysis, historical data has been explained below. However, while historical trading range refers to the highest or lowest prices a security or commodity has ever traded at, historical yield refers to the yield that has been earned by a mutual fund, usually a money market fund, over a period of time (Jain, 2010:273).
} 
The economist is also partly historian because he studies some significant aspects of the human past relating to economic activities. In fact, history has played, and continues to play, significant roles in economics because historical factors or events have influenced, and would continue to impact on, the economic lives of all human societies. The economist, therefore, could never ignore historical lessons altogether from his examination of economic phenomena. The term economics derives from the Greek words Oikos meaning a house, and Nemein meaning to manage (Kwanda Series, 2013, October:3). Today, economists usually explain economics as originally referring to the science of managing the household, using the limited money or resources a household has. With the advent of the Industrial Revolution, however, economics has come to refer to the production, distribution, and consumption of commodities (Coulter, 1994:281). Economics is naturally put in a historical framework immediately such an explanation is offered to the discipline, in the sense that the terms originally and the Industrial Revolution remind us of the past and, hence, embody history. It would, therefore, be necessary for economists to explain further to students and general readers how the household was managed and the economic developments which occurred prior to the Industrial Revolution, the changes that occurred and those which happened during this revolution and the effects of the revolution on the economic forces of human civilisation.

In examining the economic systems practised by countries today, including socialism, communism, and capitalism, economists try to put them in their respective historical contexts. For example, in tracing the origins of capitalism, economists go beyond the publication of Adam Smith's famous treatise, The Wealth of Nations, in 1776 to the era of the Crusade Wars, which sapped the energies of much of Europe from the eleventh through the thirteenth centuries. In these centuries, they examine the emergence of the commercial or mercantilist economic order, with its central focus on the exchange of goods rather than on their production. The descriptions of some of the courses run by the Department of Economics at the University of Cape Coast, including ECO 308: Economy of Ghana and ECO 402: History of Economic Thought, stress this point. ECO 308 introduces students to some of the structural features and management of the economy of Ghana. "The course also looks at the Economic Recovery and Structural Adjustment Programmes ..." of the 1980s and early 1990s (Department of Economics, "Course Descriptions", obtained on August 24, 2017). ECO 402 has been described thus,

The purpose of this course is to expose students to the foundations and development of modern economics. The course involves why we study history of economic thought, teaching pre-classical economics, classical economics, marginalist revolution, Keynesian revolution and the Cambridge revolution (Ibid.).

In fact, so close is the influence of history on economics that some discerning economists have pointed out categorically that it is manifestly impossible for economists, particularly those whose interests centre on problems of growth, to ignore the lessons of the past. This is the major reason why it is now common for courses in economics to provide for some modest exposure to economic history (Gould, 1972:xv). Many economists have, therefore, either decided to examine the historical aspects of economics or employ the historical approach to the examination of economic phenomena. By 1914, Joseph Schumpeter, for example, had produced three works, the first and third of which dealt with the problems of economic theory and the history of economic ideas (Hoselitz, 1958:vi). Again, in 1943, he turned to writing his last book on the History of Economic Analysis, because he felt that "it is simply the subject among all those at hand, that is farthest removed from current affairs" (Ibid.).

In his Theory of Economic Growth, Lewis (1965:6) states that in order to strengthen the book by including in it two or three case studies of economic growth or economic stagnation, he had to read about ancient Egypt, Greece, Rome, Islam, China, Japan and the end of the Middle Ages in order to gain some historical knowledge, especially of periods before C.E. 1500, about early economic history. To get concrete historical instances to support his study and be able to put his study in an appropriate historical framework, Lewis again collaborated very closely with Mrs. Gisela Eisner, who was writing up the economic development of Jamaica from 1830 to 1930. In his methodology, Lewis defends his leanings towards the historical approach by showing that to understand how and why something, such as growth in economics, happens, it is essential to look at the facts, that is, to apply the inductive method to historical data because the deductive method helps much less towards answering them (Ibid., p. 15). This is highly crucial because in their studies, every economist goes through a phase 
where he is dissatisfied with the deductive basis of economic theory, and feels sure that a much better insight into economic processes could be obtained by studying the facts of history (Ibid.).

In his Economic Growth in History: Survey and Analysis, Gould (1972:xvi) also opens his discussion with "Growth and Development in History" in the first chapter, which sketches the historical experience of growth in its broad contours. Due to the clear intimacy he observes between economics and economic history which has developed over the last couple of decades, and especially due to the historical approach he adopts towards his study, Gould states that "This book is primarily intended for [both] the economics student who is not quite sure what he has learned from economic history; [and] for the student of economic history who thinks he knows what he has learned from economics, but does not quite see how it applies to history ..." (Ibid.). After all, the work "... is an attempt to present some of the facts of modern (and a little pre-modern) economic history in a growth-oriented analytical framework" (Ibid.). Many other economists tread the same path, by investigating the history of the topics they examine. For example, Yakubu and Korankye (2004:295), in their Economics Textbook for Senior Secondary Schools, and Aidoo (2012:448), in his Economics Textbook for Senior High Schools in West Africa, have also examined the historical development of money. Beattie ("The History of Money: From Barter to Banknotes" (2010, February 21), retrieved March 23, 2013) has also examined the history of money from the ancient times to the present on the basis that "Money, in some form, has been part of human history for at least the last 3,000 years, [but] Before that time, it is assumed that a system of bartering was likely used." In the same way, Menger (1991:483-504) has reappraised the history of money. He argues that to understand the problem of why people exchange their goods for money, "We may look away from these forms [of coin or document, employed as current-money] and go back to earlier stages of economic development ... where we find the precious metals in an uncoined state serving as the medium of exchange, and even certain other commodities, cattle, skins, cubes of tea, slabs of salt, cowrie-shells, etc. ..." (Ibid., pp. 483-484). Some of the major themes in his work which prove his historical analysis of money are 'The Problem of the Genesis of a Medium of Exchange', 'On the Genesis of Media of Exchange' and 'How the Precious Metal Became Money' (Ibid., pp. 486-488, 493-496, and 499-502). In undertaking this study, Menger' relies on works which were compiled and published between 1871 and 1891, a clear evidence of his use of historical documents and the employment of the historical method.

As in other fields of science, the historical approach to the study of economics and economic concepts is, of course, necessary because almost all economic systems, theories and concepts have deeply entrenched historical roots. Finch (2006), for example, has emphasised clearly that the historical development and idea of analysing challenges involved in managing organisations for growth stretches back to the early stages of the Industrial Revolution in the late 1700's and early 1800's. In defence of this approach, Attobrah (personal interview: August 23, 2017, University of Cape Coast campus), an economics graduate, who read ECO 402: History of Economic Thought in his final year at the university, insists that the nature of economics and of some economic concepts and theories necessarily requires historical knowledge. He argues, for instance, that to be able to determine a person's income today and predict his income in the future, one needs a background knowledge of his past income status; without this historical background, it would be difficult to make accurate predictions about the future. In practical terms also, the production and the distribution of wealth between the rich and the poor in any society have been determined largely by historical factors. History has also played a key role in determining the differences between the wealthy and poor countries of the world today. Taking the poor economies of African countries and the rich economies of Europe and America as a case study, one could hardly play down the role of history. Here, some of the key historical factors were the institution of the trans-Atlantic Slave Trade and the excessive exploitation of the resources of Africa for the benefit of Europe and America. The economist could also not ignore the causes of the Great Depression of 1929-1933 and the social programmes which the United States government enacted to deal with the situation, in order to gain insights into what course of action should be followed in subsequent depressions and recessions. Evidently, economics is also a vassal or a subject science to history, and shall forever remain so insofar as it continues to survive, as a science, and accumulate more and more history with the passage of time. This realisation only validates the theory of historical imperialism in economics. 
Philosophy

I do need history in my field (Philosophy) because my field entails past works of philosophers which go into ancient, modern and post-modern periods. My field, obviously, requires me to use a lot of historical data. The works that I assess are historically-based, and so, in my view, they are historical data. The difference is the trend of analysis that is made. For instance, the courses I teach, including PHL 309: Political Philosophy of African Independence Leaders; PHL 311: Introduction to Marxist Philosophy; and PHL.101: Problems of Philosophy, are basically history which demands the use of historical materials and the adoption of historical approaches. PHL.101 particularly makes a historical trace of philosophy and the emerging problems therein (Abraham: personal interview, August 4, 2017, Cape Coast).

As Abraham has intimated, philosophy is concerned with, and does a great deal of, history in the sense that many contemporary philosophers study and write about the great philosophers and philosophies of the past, while institutions of higher learning also run philosophy courses that are basically historical studies. Apart from the courses Abraham teaches, most of the courses run by the Department of Classics and Philosophy at the University of Cape Coast also consist in history. PHL 304: Early Modern European Philosophy, for example, has been described thus, "It adopts a historical approach to the study of some main European philosophers from the 17th century to the end of the 19th century" (Faculty of Arts, 2013:35). The following courses and their descriptions are also significant illustrations: PHL 306: African Social and Political Thought - "This course studies elements of African social and political thoughts and their applications. It spans two broad historical periods: the pre-colonial and the post-colonial" (Ibid.); PHL 406: Philosophy of Human Nature - "It examines our estimation of the human being and the place of human kind in the universe. It adopts a historical approach for the study" (Ibid., p. 40); and PHL 811: Issues in African Philosophy - "This course offers an intensive study in some main areas of African Philosophy. These include: 1. History of African Philosophy ..." (Ibid., p. 25). ${ }^{15}$

According to the Journal of Philosophy or Mind, to look at virtually any issue of a philosophical journal is to be aware that contemporary philosophers include very many who are much concerned with the history of philosophy (Honderich, 1984:11-12). It is this aspect of the discipline which makes some people assert that a major component of philosophy amounts to the enterprise of no more than a recovery of the past. These critics are not wrong because to a considerable extent philosophy does consist in history, particularly the history of ideas, where its intention is to critically examine the doctrines and judgements of philosophers like Socrates, Plato, Aristotle, Copernicus, Kepler, Galileo, Descartes, Spinoza, Kant, Nietzsche, St. Augustine, Machiavelli, Dewey, Santayana, Burke, Marx, Frege, Wittgenstein, Russell and many others. For example, in 1945, Russell (1972:ix), himself a great philosopher, published A History of Western Philosophy, which, in 1972, was reissued by Edith Russell as The History of Western Philosophy. In the preface to this study, Russell reveals that there are many histories of philosophy. His purpose for doing this study is to exhibit philosophy as an integral part of social and political life: as both an effect and a cause of the character of the various communities in which different systems flourished. In his estimation, this purpose demands more account of general history than is usually given by historians of philosophy (Ibid.). He thinks this approach is better because after reading several standard histories of philosophy, the conclusion he draws is that very short accounts do not really convey anything of value to readers. He finds it particularly necessary to provide a detailed historical background to the period before the twelfth and thirteenth centuries because he believes that without some knowledge of the centuries between the fall of Rome and the rise of the medieval Papacy, the intellectual atmosphere of the twelfth and thirteenth centuries could not be properly understood. In dealing with this period, he aims at "giving only so much general history" as he thinks necessary for the sympathetic comprehension of philosophers in relation to the times which formed them and the times that they helped to form. He argues that topics such as the influence of Sparta on J.J. Rousseau, of Plato on Christian philosophy until the thirteenth century, of the Nestorians on the Arabs and on Saint Thomas Aquinas, and of Saint Ambrose on

${ }^{15}$ Readers should note that these are only excerpts but not the full descriptions of the courses. 
liberal political philosophy from the rise of the Lombard cities until the present-day, are some of the themes of which only a comprehensive history can treat (Ibid.).

Many other philosophers also appreciate the value of history and its impact on understanding certain philosophical topics. For example, Burtt's The Metaphysical Foundations of Modern Science (2003) is a study that falls directly under philosophy of science. However, the study, as implied in the term Foundations in its title, is totally dominated by history and, as a result, situated in a historical context and approached from a historical point of view. In this work, Burtt's aim is to describe and analyse what has been described as 'the greatest revolution in the history of Western thought', that is, the shift from the philosophy of the Middle Ages that humans were at the center of creation and that all of nature existed for their benefit, to the modern view of humanity's less central place in the universe. This work has been described as a criticism and a history of the change which made the rise of modern science possible, and as a guide to understanding the methods and accomplishments of the great philosopher-scientists of the sixteenth and seventeenth centuries (see back page). The reason is that while accounting for certain limitations in the modern perspective which continue to characterise contemporary scientific thought, Burtt also establishes the reasons for the triumph of the modern view by offering a fascinating analyses of the works of great philosopher-scientists of the sixteenth and seventeenth centuries, including Copernicus, Kepler, Galileo, Descartes, Hobbes, Gilbert, Boyle, and Newton. Actually, the book is considered either as history in the field of philosophy of the physical sciences or history in the area of metaphysics (p. 4). This is not surprising because considering the problem he identifies and seeks to investigate, Burtt maintains that there is the need for 'a much more radical historical analysis of the rise of the fundamental assumptions characteristic of modern thinking' (Ibid., pp. 17 and 29).

In their attempts to understand the establishment of the Corpuscularian philosophy, many philosophers and natural scientists learn the doctrines of John Locke and Berkeley about matter and qualities. They, however, rarely come to see them in the setting in which they were composed. This, thus, do not help them to acquire an enhanced understanding of the philosophy. To avoid this mistake and help students of philosophy get a more just view of the British Empiricists and historians of science and a better understanding of the involvement of conceptual change in scientific discovery, Harré (1964:vii) takes a historical approach by attempting to show a thread of argument which runs through both the scientists and philosophers of the seventeenth and eighteenth centuries. In his study of the place of natural law ${ }^{16}$ in Burke's political philosophy, Stanlis (1965:4) also insists that without reference to classical and scholastic natural law, Burke's political philosophy could not be truly understood. Stanlis begins his study by first trying to find out the philosophic content of natural law. Consequently, he poses the question, "What, then, is the essential content of natural law?". He adopts the historical approach towards answering the question by stating that "One way of answering this questing would be to examine what various thinkers have said concerning Natural Law, from the dawn of moral reflection to the time of Burke" (Ibid. p. 6). Considering the ancient and medieval thinkers, he selects Cicero and St. Thomas Aquinas, on the basis that the definitions they assigned natural law remain the most profound and all-inclusive, and then examine how they used the concept in their respective ages. It is only after doing this that he proceeds to the modern era to examine Burke's understanding of the natural law, and how he applied it in his practical political thoughts and practices.

It should be stated that the historical approach to the study of philosophy is preferable in several ways as it is in other sciences. In one sense, it helps in the easy assimilation of the established vocabulary of a system or a school of philosophy, and saves readers from the tragedy of mistaking a system or a school for the total truth. Again, the historical approach to the study of philosophy places philosophic thoughts in the specific conditions in which philosophic theses are born in history. In addition, it brings readers into direct involvement with the point of view of the philosophies and philosophers under review. An American graduate student (see "Why Study History", retrieved July 26, 2012) has confessed that he first began to appreciate the significance of studying history as an undergraduate student studying political philosophy at Boston University. Here, he was pretty keen on Plato, Aquinas, Dante, Hobbes, Locke, Godwin, Marx, Mill and a host of other great philosophers. He soon

\footnotetext{
${ }^{16}$ Natural Law, as used here, refers to a theory of law or a philosophy which concerns itself with ethics, law, politics and human behaviour, and not to natural laws in the physical sciences. See Stanlis (1965).
} 
discovered that his lack of understanding of history, that is, the actual historical context in which these writers conceived and executed their theoretical works, made his understanding of their philosophy one-sided. He knew what the philosophers had to say about liberty, or the proletariat, or monarchy or the franchise, but he lacked any practical knowledge about the historical environment that gave rise to their ideas. Later, he came to appreciate that ideas have a history and undergo a process of development. He, therefore, quickly turned his attention to history itself as soon as he realised this fact. Now, he adopts a historical approach to the study of the ideas of these philosophers, and this approach, he emphasises, makes him better able to visualise history in a different way, because it gives some sense of 'pastness' to the past. The question one may wish to ask is, "Why would philosophy be engaged in such a historical venture if it had no interest in history?" Any answer to this question, we strongly believe, would eventually place philosophy in a historical framework and, hence, emphasise the theory of historical imperialism in philosophy.

\section{HistoriCAl IMPERIALISM In ThE NATURAL SCIENCES}

In his The Metaphysical Foundations of Modern Science, Burtt (2003:32) makes frequent references to the history of physical science and the history of mathematics and mechanics, which indicate that the natural sciences have histories which are valued and studied by their practitioners. The scientific works of past natural scientists, including Isaac Newton's law of motion, Albert Einstein's law of gravity, etc., form the basis of natural scientific knowledge today. These historical studies have provided clues and methods for today's scientific research, and have made present natural scientists aware that a full understanding of their fields of emphasis and their sub-themes, or the various topics they examine, could not be gained until they are situated and examined in historical perspectives. Hence, modern natural scientists also consider historical knowledge very essential to their studies. This is what Bynum, Browne and Porter (1988:viii) emphasise when they state that the history of science needs a careful study because the historical dimension of science is relevant to the understanding of the place of science in our lives. In any case, Collingwood (cited in Rowse, 1946:148) has argued that natural science has always existed in the context of history and depends on historical thought for its existence.

In examining the ways by which graduate natural science teacher training courses could be structured to provide the widely diverse skills and knowledge of future natural science teachers, Watson (1962:201) recommends the inclusion of a course on the history of natural science for training science teachers. He makes this suggestion on the premise that natural science and natural scientific knowledge have evolved through several phases and would probably continue to change in the future. In view of this, he argues that some of the important factors that should be considered in training future natural science teachers are how the present curricular patterns and courses in natural science have developed through past years, and the various proposals for their modification (Ibid., p. 206). Obviously, Watson is advocating the teaching of the history of biology, of chemistry, of physics, of general science, and of elementary school science in graduate teacher training institutions in order to equip natural science teachers with a deeper understanding not only of the development of natural scientific thought and practice in times past, but also of the nature of the natural scientific enterprise and the knowledge it produces.

The realization that history is significant to the teaching, study and practice of natural science has compelled natural scientists to give special training to some of their members to examine the historical dimensions of their disciplines. Concerning the history of natural science in East Asia, for instance, there have been eminent historians of mathematics in China and Japan, including Li Yen, Ch'ien Pao-Tsung, Chang Hêng, and Mikami Yoshio; and prominent historians of astronomy, such as Leopold de Saussure, Ch'ên Tsun-Kuei, and Chu K'o-Chen (Needham, 1982). Profound exponents of the history of Taoism, alchemy, and early chemistry include Ch'ên Kuo-Fu, Li Shao-Chün, Ko Hung, and Wang Ming. Botany and agriculture have had brilliant historians such as Hsia Wei-Ying, Shih Shêng-Han, and Amano Motonosake. Li T'ao, Ch'ên Pang-Hsien, and Hu Tao-Ching have also practised the history of medicine. In Europe, too, several natural science scholars like Galen, Sir Frederick Gowland Hopkins, the father of British biochemistry; Charles Singer, eminent English historian of science and medicine; Walter Needham, seventeenth-century medical doctor and embryologist; Sir Thomas Browne, a famous English medical doctor and author; and many more 
others have done so much to reconstruct the history of the various aspects of natural science (Needham, 1982). ${ }^{17}$ African natural scientists have also made significant contributions to the reconstruction of the history of natural sciences. ${ }^{18}$

Thanks to the works of these noble scholars, who we regard as imperialist (or colonial) agents of history in their respective sciences - more appropriately as indigenous rulers, new books have appeared on all aspects of the history of the natural sciences, and really wonderful discoveries have been made, due, obviously, to the historical approach towards the study of natural science (Needham, 1982:ix). Crombie (1959:xi) confirms that one of the most remarkable developments in the world of scholarly letters from the beginning of the twentieth century, and especially since the end of the Second World War, has been the growth of the study of the history of natural science both as a professional historical discipline and among the interests of the general reader. He indicates that several works on natural science in antiquity and in modern times have been published in recent years, both separately and as part of the general histories of science. He insists that considering how natural science has quietly come to take a central position in our culture, the vigorous study of its history is very crucial (Ibid., p. xi). Astronomy, mathematics and medicine have been selected to illustrate historical imperialism in the natural sciences.

\section{Astronomy}

The term Astronomy comes from two Greek words astron and nomos, meaning star and law respectively (Porter, 1994:xi). While the Macmillan English Dictionary for Advanced Learners defines astronomy simply as the scientific study of the stars, planets, and other objects in the universe, the English Dictionary explains it as the science that studies celestial bodies, their magnitudes, motions, distances, periods of revolution, eclipses, constitution, physical condition, and the causes of their various phenomena (Princeton University, 2006). Hynek (1987:145) also explains astronomy as the science concerned with the observation and interpretation of the radiation received in the vicinity of the Earth from the component parts of the universe. However astronomy is defined, it is appreciated that the study of the stars and the planetary bodies did not start in our days. In fact, astronomy is believed to be the oldest of all the natural sciences, and as Porter (1994:xi) informs us, the origins of astronomy dates " ... back at least several thousands of years." It is even argued that careful and precise astronomical observations antedate the birth of astronomy as a science (Gorman, 1952:87). This shows that astronomy has a good historical account of its development which astronomers need to know and understand as a prelude to understanding the present situation of their science, and to know their way forward. This is to say that astronomers study the history of their discipline not only for the sake of pleasure, but also, and more especially, for the sake of knowledge for practical purposes in their field of study.

Porter (1994) has reconstructed the history of astronomy, and traces the origins of this science from the ancient Egyptians' patient study of the heavens in order to know and predict the time or date of the flooding of the River Nile for agricultural purposes, which enabled them to eventually calculate the length of the year to be 365 days by 2780 B.C.E., and later to be $365^{1 / 4}$ days long. ${ }^{19} \mathrm{He}$ also reviews the practice of astronomy in such other ancient civilisations as Babylonia, China and Greece and shows the major developments that occurred in astronomical science there. In the modern (C.E.) period, he begins with the observations of Nicolaus Copernicus (1473-1543), who demonstrated that it was possible to account for the apparent motion of the planets in the sky much more neatly by placing the Sun at the centre of the Solar system, with the planets orbiting about it, than by geocentric theory (p. xii). He then proceeds to Tycho Brahe (1546-1601), whose works threw more light on the Copernican revolution and helped the invention of the Gregorian calendar, instituted in 1582; Johannes Kepler (1571-1630), who used Brahe's observations to establish the heliocentric theory of

\footnotetext{
${ }^{17}$ Throughout his study, Joseph Needham makes mention of several Asian, European and American historians of natural science and specifies the specific fields in which these scholars dwelt for emphasis. For details, see Needham (1982).

${ }^{18}$ There are so many historians of the natural sciences whose names could not be mentioned here.

19 As a proof of Porter's assertion, Russell (1962:9) emphasises: "When the Greeks began inventing astronomical hypotheses, the apparent motions of the sun and moon and planets among the fixed stars had already been observed for thousands of years by the Babylonians and Egyptians, who had also learned to predict lunar eclipses with certainty and solar eclipses with a considerable risk of error."
} 
the Solar System once and for all; Hans Lippershey (1587-1619), the inventor of the telescope in 1608; and Galileo Galilei (1564-1642), who quickly used the telescope to discover the phases of Venus, and to identify four satellites of Jupiter. Porter also discusses Galileo's establishment of the stellar nature of the Milky Way, and his discovery of spots on the Sun and mountains on the perfect sphere of the Moon (Ibid., p. xiii).

Porter's account shows Isaac Newton's (1642-1727) discovery of the law of universal gravitation in 1665 as the next major breakthrough in the science of astronomy. He refers to the building of the first reflecting telescope in 1668 as another major Newtonian contribution to observational astronomy. From here, the next phase of astronomical development was Charles II's founding of the Royal Observatory at Greenwich in 1675 essentially to find an accurate way of determining longitude for British ships involved in overseas exploration and colonisation. After recounting John Flamsteed's (1646-1719) drawing up of a new star catalogue - the first map of the telescopic age, and emphasising that the true nature of the star Flamsteed noticed at 34 Tauri was discovered by William Herschel (1738-1822), Porter now examines the rest of the development of astronomy under major themes. The period from the beginning of the nineteenth century to about the second decade of the twentieth was devoted to the development of astrophysics, while the twentieth century saw determined attempts to study the origins of the universe, and the development of satellite and spaceprobe astronomy and new telescope (Ibid., pp. xiv-xvi). In this analysis, Porter does not explicitly state his reliance on historical data, but we do not need to undertake any controlled observations to agree on his use of historical materials. Link (1969:9) even supplies us with evidence here. In examining 'The History of Lunar Eclipses', he describes lunar eclipses as one of the oldest celestial phenomena, reported in historical sources. What is more important, however, is that Porter tries to establish connections between astronomical developments in earlier and succeeding periods, so that events in the earlier ages set the background for those in subsequent eras, while discoveries and inventions in later periods display the effects of what happened in earlier ages. In recounting the history of astronomy, therefore, Porter tries to play the historian by establishing cause-and-effect relationships between past and present events. This attempt is meant not only to show the efforts of precursors or improvements followers made to the works of their predecessors, but also to emphasise that the status of astronomy today is the collective product of the shared labours of all past and present astronomers. Hence, a full understanding of the present of astronomy requires a knowledge of its past.

Also, on April 12, 1965, it was announced that Soviet astronomers had observed a radio beacon apparently created by a super-civilisation seeking to draw attention to itself across the vastness of space. This was cited as evidence that there might be life on other planets so that humans on Earth are not alone in the universe. Inspired by the announcement, Walter Sullivan, the Science Editor for The New York Times, undertook a study, We Are Not Alone: The Search for Intelligent Life on Other Worlds, which was published in 1966. In this work, the important questions Sullivan examines include: is our universe unique; are there visitors from space; what if we succeed in making contacts; and is there a "uniquely logical" channel of communication? In answering these questions, Sullivan offers readers a general tour of the universe, showing the possibility that we share it with other civilisations on other planets. For a good treatment of the topic and for the proper understanding of readers with minimum background in science, however, he adopts a historical approach towards his problem. He is of the view that to understand how the question of life on other planets became very important in the second half of the twentieth century, "it is necessary to retrace the evolution of man's concept of the cosmos, and his place in it, that has occurred since our ancestors first began to wonder about such things" (Sullivan, 1966:3). With this conception, he discusses the full historical background of scientists' attempts to communicate with other worlds. He begins with the Greek astronomers with their fixed stars and planets, through the Renaissance with its spinning Earth, to our own huge universe of many galaxies. He examines earlier discoveries concerning Mars and the possibility of life there that came out of the voyage of Mariner 4, which past that planet in 1965. With this approach, Sullivan offers readers a full historical background of humans' changing ideas of the mortal conflicts, the debates, the reasoning, the false starts, the theories, and the investigations that have brought humans to the very threshold of contact with other worlds in our galaxy. The work is, thus, considered both as a history of humans' longing to reach beyond their world for a better one and as a report showing just where we are today in an age-old quest to understand the universe. 
Sullivan's work is truly a historical study of some major aspects of astronomical science which contributes much towards our understanding of the present stage of astronomy. Some revelations from Tayler (1970) would help illustrate this point and make it even clearer. In his The Stars: Their Structure and Evolution, he intimates,

This book is concerned with the structure and evolution of the stars, that is the life history of the stars. Its aim is to show how observations of the properties of stars and knowledge from many branches of physics have combined, with the aid of the necessary mathematical techniques, to give us what we believe is a good understanding of the basis of this subject (p. 1).

In saying this, Tayler is confirming the historical study of the stars. To illustrate his employment of the historical method, he states that he presents his analysis of the development of the study of the stars "... in a completely logical manner in which each step follows smoothly from the previous one" (Ibid., p. 6). A major benefit Tayler enjoys from this approach at the end of the study is his realisation of the truth that there are several unsolved problems concerning stellar structure and evolution, but the amount of progress that has been made in the subject is very great. Based on his knowledge of the past of astronomy, he understands that the present problems of the science emanate mainly from the disparity between theory and observation. The view he then has of the future of the discipline is, "For that reason, interest will be paid in the next few years to the ultimate resolution of the present discrepancy between theory and observation in the solar neutrino experiment" (p. 196). Indeed, if astronomy studies its history, employs the historical method, and derives the advantage of understanding its past and present and foreseeing its future, then the science is genuinely entangled in the imperial chains and fetters of history.

\section{Mathematics}

The term mathematics comes from the ancient Greek word $\mu \dot{\alpha} \theta \eta \mu \alpha$ - mathema - meaning subject of instruction. ${ }^{20}$ The Pythagoreans, who coined the term, are believed to be the originators of the study of mathematics as a demonstrative discipline beginning in the sixth century B.C.E. Many are the people who think that disciplines like mathematics do not need and concern themselves with history, probably because it deals mainly with pure abstractions and proceeds deductively from axioms to theorems (Palmer and Colton, 1964:264). ${ }^{21}$ Such a conception is, however, grossly erroneous. Even if we decide not to make any reference to historical imperialism in mathematics, we still could not leave the territory of mathematics without smelling history around. The first two sentences in this paragraph quickly draw our attention to the fact that mathematics has a history traceable from the time of its evolution as a demonstrative science in the sixth century B.C.E. to the present. Aware of this, and inclined to help the reading public understand how mathematics got to where it is today, historicallyconscious mathematicians pay attention to a critical analysis of the history of mathematics.

Apart from exploring their main history, some mathematicians adopt the historical approach in dealing with some branches or themes in their studies, in view of the desirability of analytical narratives to their appropriate understanding. Geometry, for instance, has been given this treatment by several mathematicians. Geometry comes from the Greek word geometrein which is a combination of geo - earth, and metrein - measure. Hence, in its original sense, geometry is the science of measuring land (Greenberg, 1984:5). In modern science, geometry is the branch of mathematics which investigates the relations, properties, and measurement of solids, surfaces, lines, curves and angles (Princeton University, 2006). Considering both the original and contemporary focus of geometry, the question one may wish to ask here is, "In what ways do the influence and authority of history manifest themselves in the territory of geometry?" Put differently, "What evidence do we have to show that the imperialist proclivities of history are observed in the science of geometry?" Greenberg (1984)

\footnotetext{
${ }^{20}$ Note that the term calculation, commonly associated with mathematics, is a Latin word and means $a$ handling of pebbles. According to Russell (1972:22), Pythagoras developed a way of representing numbers as arrangements of dots or pebbles, a method of reckoning which in some form or other survived for a long time. In essence, calculation derives from the works of Pythagoras.

${ }^{21}$ Closely related to mathematics is the science of statistics. Ludwig von Mises (1991:94) maintains that the material statistics provides is the outcome of a complexity of forces and so statistical material are historical. He states categorically that what the statistician establishes in studying the relationship between supply and demand is of historical importance only. He, therefore, regards economic statisticians as historians (Ibid., p. 96).
} 
provides us with empirical evidence; he describes his Euclidean and Non-Euclidean Geometries: Development and History as "... a rigorously, historically motivated presentation of the foundations of geometry" (p. xii). In effect, he begins the study with a brief history of geometry in the ancient times. After stating that Herodotus credits ancient Egyptian surveyors with the invention of geometry, he shows that the science was also practised among the ancient Babylonians, Hindu, Chinese, and Jews, although at this time geometry was based mainly on trial and error. Beginning with Thales of Milete, Greenberg highlights the contributions the ancient Greeks also made to the development of geometry, insisting that geometric statements should be established by deductive reasoning than by trial and error. He highlights Thales' development of the first logical geometry, which was continued over the next two centuries by Pythagoras and his disciples. He also examines the works of the mathematician Hippocrates (not the physician), Eudoxus, Plato, and now comes to discuss the magnificent contributions of Euclid, a disciple of the Platonic school who founded a school of mathematics at Alexandria and produced the definitive treatment of Greek geometry and number theory in his thirteen-volume work, The Elements, around 300 B.C.E. (Ibid., p. 7). What makes The Elements a magnificent work is that in compiling his work, Euclid built on the experiences and achievements of his predecessors in preceding centuries; and the complete nature of the work also supersedes earlier attempts at presenting geometry. These facts help teachers and students of geometry to understand why Porter (1994:xiv) describes The Elements as a work which records the development of mathematical knowledge in early Greece and is, thus, intended as much as a history of mathematics as a compendium of knowledge. They also answer the question of why Euclid is reportedly the most widely read author in human history (Greenberg, 1984:7).

Lucas and James take off from where Greenberg left off. In examining the history of geometry in their New Mathematics for Senior Students: Mathematics II, they (1972:27) do not begin their trace from the pre-Euclidean period. They start rather with an evaluation of the strengths and weaknesses of Euclid's work and show that in spite of its flaws, it was not until the sixteenth century that the first breakaway of note from his treatment occurred. This was when the French philosopher René Descartes (1596-1650) introduced the apparently simple idea of using co-ordinates - or graph paper, in simple language - to specify the position of every point of a plane by the Cartesian product $\mathrm{X} \times \mathrm{Y}$, and even proved every one of Euclid's theorems analytically (Ibid., p. 62). The details of the accounts presented by both Greenberg, and Lucas and James indicate that to gain a good understanding of the present state of geometry, geometers in particular and mathematicians in general must know the historical circumstances that gave birth to their noble science. What makes this a serious requirement is that Euclid's approach to geometry has dominated the teaching of the subject for over two thousand years, with The Elements still being considered as a standard textbook even at the beginning of the twentieth century (Ibid.), while the axiomatic method used by Euclid is the prototype for all of what is now called pure mathematics (Greenberg, 1984:7). Certainly, this historical analysis of geometry helps teachers and students of the science to understand not only the tremendous debt contemporary mathematicians owe to Euclid, but also the historical processes or circumstances through which geometry evolved as a well-recognised science, as well as the connections between the past and present of geometry. Taking all this into consideration, would it not be a big blunder, even suicidal, for geometers and mathematicians to ignore the study of the history of geometry, at least from the Euclidean era, and to abandon the use of the historical approach?

Some mathematicians even argue that the use of historical perspectives in teaching mathematics helps in clearing the impression that mathematics is the most phobia generating subject in the school curriculum. For example, in his "The Teaching of Mathematics", Sawyer (1962:221) observes that the purpose of modern mathematics is often obscure to students because of their lack of an understanding of the historical background of the discipline. He posits that twentieth-century mathematics was built on the foundations of nineteenth-century mathematics; however, students are often not familiar with nineteenth-century mathematics. To him, mathematics students' lack of the historical antecedents of modern mathematics is the reason why they could not possibly see the motivation for more recent works. He argues further that even where new branches arise, the new ones could be traced from particular problems in the older branches of mathematics. He supports his assertion with strong evidence of varied cases where new works have sprung from old ones. He shows that Cantor's study on sets and transfinite numbers, for instance, grew out of his study of Fourier series; and topology was 
stimulated by the theory of the Riemann surface and of integration over complex numbers. ${ }^{22}$ The conclusion he draws from this analysis is that if students are not aware of these historical connections, they are bound to be mystified (Ibid.). To correct this error, he examines the purpose of the study of arithmetic in a historical context, by indicating that about a century back from the mid-twentieth century, the purpose of arithmetic lessons was to produce clerks who could keep accounts accurately. He then analyses how the achievements of arithmetic declined and how the science lost purpose in the early twentieth century. Finally, he points out the failure of arithmetic text during the 1920-1950 period to have the object of stimulating interest and intellectual curiosity (Ibid.).

Sawyer adopts the historical approach in treating the purpose of the study of arithmetic because he identifies historical knowledge as a qualification for a knowledge and understanding of the present and the future of the science. Here, he demands that students should know enough about Fourier series in order to appreciate their historical significance and to realise how such a series can behave unexpectedly (Ibid., p. 230). Mosvold (2005) strengthens the position of those historically-conscious mathematicians who advocate the incorporation of historical analysis into the teaching and learning of mathematics. In his Master of Science thesis, he discusses the use of history in teaching mathematics according to the genetic principle. He emphasises,

In my M[aster of] S[cience] thesis I indicated a theory of genesis that not only concerned incorporating the history of mathematical ideas, methods and concepts, but was more a way of defining the learning of mathematics as a process of genesis, or development. This process could be historically grounded, in what we might call historical genesis (or a historical genetic method) ... (p. 1).

Evidently, mathematicians, no less than any other scientists, need and rely on historical data in examining some of their topics and, hence, use the historical method, due mainly to the influence of history on their studies. This is a clear manifestation of historical imperialism in mathematics.

\section{Medicine}

So why should I - a pragmatic surgeon - wish to look over my shoulder at the history of medicine, or take time to nod to the innovators of former ages? The simple answer is that history is important, and that when I gulp for air to escape the deluge of up-to-the-minute information, it is the air of historical perspective that I seek. In fact, this is indispensable if we want to try to understand the present and anticipate trends for the future .... In my view, the stories of such battles, of the frustrations of researchers, the perseverance of individual physicians and the victories and defeats of the whole medical profession, should be told - and taught - again and again. But what I find most attractive about this book [A History of Medicine: From Prehistory to the Year 2020] is that it ... gives the facts to those of us in medicine who are looking for historical perspective ... (van Urk, 1992:6).

The term medicine comes from the Latin word medicus, meaning physician. Medicine is the science and art of diagnosing, treating, and preventing diseases and injuries, with the view to helping people to live longer, happier, and more active lives with less suffering and disability. As a science and a practice, medicine has a very long history which is traceable to the prehistoric times. This implies that there is a branch of knowledge called history of medicine which could be subjected to a historiographical analysis. Evidently, in medicine, too, history rears its imperialist head. In spite of this truth, Brandt (1991:199) has lamented that it is rare for history to be considered as a part of the medical sciences, nor is it included for analysis in conjunction with health policy issues. He shows that in an attempt to prove the historicity of medicine, the Milbank Quarterly has, since about 1976, become a prominent home for historical scholarship. This development is a reflection of David Willis's commitment to the idea that a broad historical knowledge and perspective would help

\footnotetext{
22 Other examples Sawyer gives to substantiate his claims are that Lebesgue's use of sets was intimately connected with the theory of integration; Hilbert space and Banach space began with the theory of integral equations; and Fréchet's work on metric spaces grew from a variety of topics in analysis. See p. 221 of his paper.
} 
medical practitioners to understand the nature of medicine in society. Spurred on by this commitment, Willis - editor of the Milbank Quarterly - has offered the pages of the Milbank Quarterly to a wide variety of historical approaches and themes (Ibid). What Brandt says here about David Willis and the Milbank Quarterly substantiates Professor Dr. Hero van Urk's expressions about the essence of historical perspectives in medical science and the practice of history in medicine. Prof. Urk's description of Duin and Sutcliffe's book, A History of Medicine: From Prehistory to the Year 2020 (1992), not only provides evidence of historical imperialism in medicine, but also gives reasons as to why medical practitioners could not survive without historical perspectives in their practice. Brandt's essay, "Emerging Themes in the History of Medicine", does not necessarily reconstruct the history of medicine; rather, it reviews current themes in works on medical history in the Milbank Quarterly or assesses the contributions of the Quarterly to history (1991:199). However, the first theme of the work, titled 'Medical History as an Emerging Field', provides critical and useful insights into the study and practice of history in medical science. In effect, this part of Brandt's essay serves as evidence to test and confirm the theory of historical imperialism in science in medicine.

Brandt sets off by first examining a lecture delivered in 1947 by Henry Sigerist to the Johns Hopkins Medical Club. In this lecture, Sigerist outlines the genealogy of the field he had played a critical role in building. He pays homage to Billings, Osler, Welch, and Kelly, the great founders of the Hopkins institutions, and notes their considerable interest in the history of medicine, and then outlines the critical shift in medical historiography that had occurred in the last years of the nineteenth century and the first years of the twentieth. Readers are informed that prior to this time, the history of medicine, as a special field of study, had little definition because it was indistinguishable from the study of medicine proper, but it was of considerable significance, in the sense that medical doctors read historical books on medicine in order to learn how to treat their patients (Brandt, 1991:200). An interesting point Sigerist makes here is that by the time the Johns Hopkins Institute of the History of Medicine was founded in 1929, the days of reading Hippocrates and Sydenham for therapeutic ideas had come to an end; medicine had become more scientific. However, medical practitioners could not do without historical perspectives and knowledge. Sigerist emphasises that the very people who had introduced scientific medicine to the United States were those who insisted on a critical role for the history of medicine. He says, "They were medical humanists who were conscious of the point in the historical development at which they stood. Their teaching was scientific, but imbued with humane and historical considerations" (Ibid.). It is significant to note that the medical history of this period emphasised two critical themes in the medical past that were appropriate to developments of the period: the development of medical knowledge - an obvious attempt to connect contemporary aspects of medicine to past inquiry - and the rise of a medical profession with humanistic foundations (Ibid., p. 201). It is equally important to note that studies in the history of medicine were

... primarily conducted by physicians within medical institutions ... [and] Medical students and members of the profession of course constituted the principal audience for such studies, which were viewed as having a clear utility within the contemporary medical world. Medical history reflected the compelling issues and questions within the medicine of the day; history was the antidote for a brave new world of medical practice that many feared would lose its ties to the past (Ibid.).

Clearly, Brandt's account highlights the fact that medical science has a history, and professional medical scientists of the first half of the twentieth century studied and practised history in their field. The same development continued in the second half of that century, although at this time, the emphasis shifted more from political and economic history of medicine towards what has come to be called the new social history of medicine. Whatever the focus of the history of medicine in the closing decades of the twentieth century, the fact still remains that research works conducted and compiled at this time had explicit historical arguments and had great impact on historians of medicine (Ibid., pp. 203-204). Medicine did not abandon the study of its history; as Brandt stresses, “... the new social history of medicine ... in the last three decades [of the twentieth century] has opened a new window on the past; indeed, the distinction between medical history and social history has become increasingly obscure" (Ibid., pp. 207-208). For contemporary historians of medicine, therefore, a vast, new area of medical history has essentially been opened for critical assessment. It is crucial to observe here that like all other scientists, professional medical practitioners study the history of medicine in 
order to understand the changing patterns and stable trends - changes and continuities - in medicine and medical health. Brandt, for example, has emphasised,

Given my essential argument that medical historiography is fundamentally influenced by the principal questions affecting medicine in contemporary life, there is every reason to believe that the study of the history of medicine will necessarily continue to change in the future as medicine and its meaning, nature, and knowledge base continue to change (Ibid., p. 209).

In his concluding remarks, he maintains that the study of history offers medical scientists an avenue to better understand critical aspects of human motivation, organisation, and relationships, which, ultimately, enables them to learn about the constraints and prospects of the human condition across time and cultures. He stresses that "Just as it did for Sigerist, the present will continue to shape our questions, approaches, and concerns. In the years ahead, historians of medicine will look again to the past, to cull the historical record for new and more sophisticated ways of understanding the present and facing the future" (Ibid., p. 211).

The single most outstanding idea in Brandt's comments is that medical science would continue to accumulate more history and, hence, continue to study its history. This implies that medical science could never survive without historical data and perspectives. Needless to say that the historical approach to the study of medicine is, certainly, appropriate in the sense that the institution of medical practice in its entirety has a very long history, which is traceable to the ancient times, the times of ancient Egypt, Babylonia, Islam and Byzantium, even before the great ancient Greek medical doctors such as Democedes of Croton, who was a physician to Darius, and Hippocrates (460-370 B.C.E.), the founder of scientific medicine and of medical ethics (Caldwell, 1965:255), emerged. Berryman (2010, July-August:1) has also observed that the belief that exercise could be considered medicine, or part of medicine, dates back to the two most prominent physicians of the ancient world: Hippocrates and Galen (129-210 C.E.). In fact, without a knowledge of its historical roots, medical science today could never claim to be complete in itself. The Hippocratic Oath, administered to graduates of medical schools today, expressing the highest ideals of the medical profession, would be meaningless to medical professionals if students of medical science are not taught the history of the medical profession and, especially, the practices of Hippocrates. That is the more important reason why a great body of medical writings composed by Hippocrates and his followers exists and is studied by medical students today.

Note also that even in their actual practice, medical practitioners depend heavily on historical knowledge for success. In dealing with diseases and illnesses, epidemiologists and health service planners often use a matrix for placing everything known about a particular disease or condition in the sequence of its origin and progression when untreated, a scheme called the natural history of disease (Sultz and Young, 2004:6). It is usually when the causes and stages of a particular disease or condition are defined in the context of its natural history that they could be matched against the health care interventions intended to prevent the occurrence of the condition or to contain its progress after its onset. It is, therefore, not surprising that in general medical practice, physicians arrive at a diagnosis only after asking for the patient's medical or health history, that is, previous illnesses of the patient and those of the parents or related members. Medical authorities say, for example, that more than fifty percent (50\%) of people who suffer from gout have a family history of the disease, and a sufferer of the disease, called Alfred, confirms that both his father and grandfather had gout (Watch Tower Bible and Tract Society of Pennsylvania. 2012, August:24-25). Indisputably, the study of the history of medical science and historical knowledge of patients' sicknesses are essential because they are the foundations upon which the medical advances of today and tomorrow would be built to make people live longer and healthier lives. Indeed, eminent scientists, doctors and surgeons have been able to produce fascinating accounts of the way that they see the science and practice of medicine developing over the next 30-odd years, each in their chosen field due primarily to their historical knowledge of medicine (van Urk, 1992:6). In any case, we have had evidence of historical imperialism in medical science and, ultimately, in science in general

\section{AnAlysis AND CONCLUSION}

At the onset of the study, we indicated that our objective was to formulate a theory of the relationship between history, on the one hand, and all other sciences, on the other hand, in the context of historical 
imperialism in science. For purposes of clarity, intelligibility, and offering readers a view of what we sought to do and the conceptual framework in which we sought to situate and examine the problem or question of the study, we explained such concepts as theory, science, history and imperialism. Again, we used evidence provided by the practitioners of the social and natural sciences to provide a theoretical foundation for the work. We then made an arbitrary selection of accounting, economics and philosophy from the social sciences; and astronomy, mathematics and medicine from the natural sciences to demonstrate how the scientists of these disciplines actually study and practise history in their fields of study and, accordingly, employ the historical method and use historical data.

Ultimately, the analysis has been able to establish that history is naturally entrenched in every science or that it has a dominant influence in all sciences. This idea is what Lord Acton (cited in "Historical Quotes", retrieved July 29, 2012) conveys when he maintains that history is not only a particular branch of knowledge, but also a particular mode and method of knowledge in other branches of science. Joachim Wach (cited in Kitagawa, 1968:viii) has also argued that understanding in every field of knowledge is conditioned, among other factors, by history. This shows that no science could be studied and appropriately understood without historical perspectives. It also emphasises that most, if not all, scientists study and practise history in their areas of specialisation and absorb the historical method into their methodologies, in order to know and understand their origins and growth, and the major developments that have shaped their course to the present. There is no properly organised body of knowledge or branch of science that does not depend, for the development and understanding of a greater part of its operations, on an understanding of history and the application of historical methods. Thomas Carlyle (cited in "Historical Quotes", retrieved July 29, 2012) has even asked, "What is all knowledge except recorded experience, and a product of history?" All this justifies the view that history is an imperialist science from whose grips, domination and dictates no science could ever escape. Taking all this into consideration, it would be logical to state that history is not just a subject but a house in which all sciences dwell. Of course, history is everything, and so a scientist who does not know history, does not know anything; he or she is like a leaf that does not know that it is part of a tree (Michael Crichton, cited in The Quotes Garden, "Quotations about History", retrieved June 7, 2013).

When it comes to research methods also, there is a great deal of history in even the scientific method. It is appreciated that the invention of the scientific method has contributed immensely to the acquisition and growth of knowledge. What is often glossed over is the historical nature of the scientific method. It is generally believed that the invention began in ancient Greece, with the development of logic and metaphysics. It, however, did not reach its peak until nearly two thousand years later, when the European Renaissance reopened these fields of inquiry. Henceforth, the rate of growth of knowledge has been extraordinary compared with anything that went before (Lewis, 1965:165). This method has never enjoyed a status of stability in its historical development. There have been variations in the areas of emphasis from one generation of methodological development to another. Caws (1967:340) has identified three main tendencies associated with three significant periods of philosophical activity in the field. During the era of ancient philosophy, the scientific method consisted of principles laid down as regulative for the acquisition of knowledge of the world in general; in the era of early modern philosophy, it consisted in the principles laid down as regulative for the acquisition of the special kind of natural knowledge known as scientific; while in the last two centuries it has embodied the principles abstracted from the practice of persons successfully engaged in the acquisition of scientific knowledge. By implication, the scientific method is inseparable from the entire history of science. Hence, in using the scientific method, scientists are only utilising a method that is a product of a long history from which it could not extricate itself.

From this argument, the scientific method is clearly a historical method. However, even when we reject this argument as being extremely philosophical, we still could not deny the historicalmindedness of scientists in their research works and the generally historical nature of research works. In fact, if history is restricted solely to its original sense as an inquiry, then all scientists and all other people who ordinarily carry out research into particular subjects or topics are historians. This, as already noted, is because the Greek term ' $1 \sigma \tau$ opía, or the Latin historia, or the English history, originally meant research or any learning or knowing achieved through a vigorous and critical inquiry, and implies the act of judging the evidence in order to separate fact from fiction. The term research could, certainly, imply any sort of critical inquiry into what is the case as well as into what has 
happened. Any investigation into any phenomena at all is, consequently, historical in the first instance. In his rectorial address at the University of Berlin in 1874, Theodor Mommsen (cited in Barzun and Graff, 1977:xx) emphasised this point. He informed his audience,

Every one of you gentlemen, every thinking man generally, is always searching for sources and is a pragmatic historian. There is no other way to understand the events that take place before your eyes. Every business man who handles a complicated transaction, every lawyer who studies a case, is a searcher for sources and a pragmatic historian.

To make the point clearer, note that researchers in all sciences depend so much on historical records in their research activities. Essentially, research works are categorised into three major divisions, namely empirical studies, review studies and theoretical studies (Maner, 1996:168). Out of the three, it is only empirical studies that appear to be somehow independent of historical foundations. For they are studies that give the results of original research projects; they present the stages in the research process by dividing it into introduction, methodology, results and discussion, and conclusion. The success of the remaining two, that is, review and theoretical studies, is, however, dependent on historical information so that such studies could not proceed further without historical data. The fact is that review studies critically evaluate previous research by defining a research problem, summarising previous studies, analysing relations and contradictions in earlier findings, and suggesting directions for further research. Theoretical studies, on the other hand, use previous research literature to advance a theory, to analyse flaws in an existing theory, or to show one theory's superiority over others. They refer to empirical studies only to illustrate theoretical points. Obviously, both review and theoretical studies concern themselves with history inasmuch as they consult past studies, which, in their time, also consulted past studies, and on and on and on. It is now evident that the success of virtually all research works hinges on the support of historical data, and so the findings of these studies and the conclusions which derive from them are more dependent on history. Indeed, in the context of the term inquiry, all sciences have some stake in investigating the past. Apparently in line with these conceptions, Barzun and Graff (1977:ix), both professional historians, believe that their study, The Modern Researcher, which one may consider as primarily meant for historical scientists, is useful to anyone, including students, government experts, lawyers, journalists, business executives, editorial assistants, club secretaries, natural scientists, as well as professional scholars or scholars by necessity, who is or would be engaged in research and report writing, regardless of his or her field of interest (p. $\mathrm{x} 1)$.

Moreover, history itself, as this study has emphasised, is highly pervasive and spreads its influence and power into the territories of all other sciences. Every science has its history, on which it depends for examining its evolutionary course and measuring its achievements. In their research and teaching activities, therefore, most scientists rely on historical materials and, for that reason, often approach their analyses from historical perspectives. To be able to understand the present stage of general natural scientific thought requires the art of understanding the scientific thought of the past. As a result, the practical inventions and achievements of natural science could be better understood by, first, putting them in a historical context. No natural scientist is, accordingly, better equipped to interpret the present if he does not have adequate historical knowledge about his field of specialisation. Undoubtedly, the natural scientist, like the historical scientist, urgently requires a knowledge of the past for an understanding of the present, in order to gain an insight into the future. Historical consciousness in the natural sciences is, certainly, highly essential in the sense that some of the useful scientific theories that obtain at present in these areas are the cumulative products of the histories of those sciences. The current theory of gravity, for example, has been verified by innumerable well-formed experiments in the past. Consequently, to be able to apply them appropriately in their practical contexts today requires a knowledge of their background, which would furnish the natural scientist with information regarding the processes of their formulation, why they supplanted previously existing theories and how they proved successful where others had failed to provide satisfactory descriptions and explanations of natural phenomena.

James' (1971:19) assertion that "history is the great humanizer; for one can give humanistic values to almost anything by teaching it historically" is, to a large extent, true. All sciences, irrespective of their nature, are humanities when taught with reference to the successive achievements of the geniuses to 
which they owe their being. In James' view, not taught thus, literature remains grammar, art a catalogue, history a list of dates, and natural science a sheet of formulas and weights and measures. It then follows that history is a background for all other sciences. Basically, as the historian performs tasks that are generally believed to be the preserve of specialists in other domains, so do other professionals need and concern themselves with investigations into aspects of the past. As Arthur Schlesinger Warnas (cited in Singh, 2006:112) has pointed out, "No individual let alone a social scientist, can wisely ignore the long arm of the past." This is due to the fact that human thought in every field of human endeavour seems to run to history, consequent on the fact that history affects all other departments of mental activity. In view of this, we could argue that all the sciences are integral parts of history, that they came into being out of the womb of history, from where they find, in greater or lesser degree, subject-matter and material, and verification or contradiction (Rowse, 1967:v; Barzun and Graff, 1977:204). It is this element of all the sciences which has shown that the historian could, and, if possible, must always, depend on virtually all scientists for data in his reconstruction of the past. On the inter-disciplinary approach to the reconstruction of the past, J. Desmond Clark (cited in McCall, 1969:28) has stated categorically that our present knowledge of the earliest stages of human culture has been built up with the aid of scientists in several disciplines, including the geologist, palaeontologist, zoologist, soil chemist, and botanist. It is the same fact Mises (1991:103104) highlights when he advises that in their research works, historians should establish the facts as far as possible by the employment of all the means provided by the theoretical sciences of human action and by the natural sciences. Just as the help of the human anatomist is crucial for the interpretation of the nature of a particular fossil skull, so is the help of these other scientists, and it is only by enlisting their aid in interpreting evidence collected by the historian that we shall be able to arrive in the end at a clearer picture of human evolution.

This practice of material and methodological give-and-take between history and other sciences appears to create the impression of a power-equilibrium or a balance-of-power relationship between them, and, then put other sciences on the same level of authority with history. As we have indicated above, accepting this view entirely without a critical analysis would amount to demoting history and depriving it of its enviable emperorship. The exchanges, in our view, should rather be understood in the context of the effects of imperialism - costs and benefits. With regard to imperialism in inter-state relations, Lewis (1965:371) has intimated that the effects of imperialism on subject peoples vary from one extreme to another, according to the treatment they receive. At one extreme, subordinates may be wiped out altogether. This is often the case in the worst empires which usually bring pillage, and slaughter and slavery in their train. At the other extreme, they may make rapid economic and cultural progress than ever before in their history. This is often the case in the best empires; they add greatly to human happiness - they establish peace over wide areas, build roads, improve public health, stimulate trade, introduce improved systems of law and new technical knowledge, etc. (Ibid.). The relationship between history and the other sciences shows, in our opinion, that history presides over one of the best empires, a federation of states, but not always with the notion of equality. Hence, the benefits other sciences enjoy from history are to be measured in terms of the costs of imperialism - or should be considered as benefits of vassalage or colonialism. Against these costs, imperialist powers derive benefits from conquests, including the acquisition of raw materials for feeding metropolitan industries, fertile lands for agricultural purposes, mineral-rich lands for exploitation, slaves to serve as a cheap source of labour, and valuable trading concessions, whose total value may be much greater than the costs of imperialism.

At this point, the question one may perhaps ask is that if it is true that history dominates the field of science, then why is it that it does not enjoy the same amount of privilege that other sciences, particularly the natural sciences whose utility is stamped upon the face of the disciplines, enjoy today? Again, do all scientists acknowledge the influence and value of history in their studies and practices? Certainly, history, as Adjepong, Oppong and Kachim (2017, April:237-280) have shown, is now struggling for a place in the school curriculum; it is one of the marginalised subjects in many schools at present, while academic historians do not enjoy the same amount of privilege and fame which their predecessor generations enjoyed. It is also true that some scientists do not appreciate the value of history in their fields of study and practice. For example, in the 1920s and 1930s, some Western social anthropologists, reacting against the pseudo-historical hypotheses of the preceding generation, went so far as arguing that history could never be relevant for social anthropologists, whose proper concern is with structural relations, and not with historical ones. Some of Radcliffe-Brown's earlier 
anthropological studies expressed this view (Vansina, Mauny and Thomas, 1964:70, footnote 28). In the real sense, however, the seemingly weak position of history among the sciences at present and the unfortunate remarks made by some scientists could be better understood in the context of the nature of imperialism. As Professor Seeley (cited in Hobson, 1902:6) has well remarked,

When a State advances beyond the limits of nationality its power becomes precarious and artificial. This is the condition of most empires .... When a nation extends itself into other territories the chances are that it cannot destroy or completely drive out, even if it succeeds in conquering, them. When this happens it has a great and permanent difficulty to contend with, for the subject or rival nationalities cannot be properly assimilated, and remain as a permanent cause of weakness and danger.

Lewis (1965:373-374) has also noted that,

Imperialism may pay handsome dividends for two or three centuries or more, in slaves or tribute or trade, but it brings its own nemesis. Inside the empire the subject peoples tend to revolt sooner or later - all the sooner if they are well treated, for then they benefit enormously both economically and culturally, and come all the quicker to resent their inferior status. In the best empires inferior status disappears more or less ...; the centrifugal forces of local nationalism tend always to break it up. Or, even before the subject peoples break away, the empire may be destroyed by its external enemies. The larger and richer the empire, the more it is envied by the have-not nations. Coalitions are made against it, hemming it in on all sides. Its defence becomes increasingly costly. ... Then it is merely a matter of time before the empire disintegrates, yielding to both internal and external pressures.

In our view, this is exactly the condition in which history finds itself. History has treated its subjects all the sciences - so well, and after benefitting so much from this good treatment, some of them have formed an alliance to overthrow their overlord. It is sad, unfortunate and regrettable; but it is equally interesting in the sense that the overlord-vassals relationship between history and all sciences is a natural phenomenon, unlike the cultural one between nation-states. Should it even happen that all the sciences combine and conspire against history, none of them could ever claim to be independent of history at any point in its life. Even when they die and reincarnate, each would still be born out of the womb of history and continue to accumulate more history as it grows. In effect, the assaults on history by some scientists in an attempt to revolt against history would forever remain a fruitless venture. They may decide not to have anything to do with history, but they could never free themselves from the chains and fetters of history; for history is an eternal emperor in the empire of the sciences. At this juncture, it should be clear to our readers that what we call historical imperialism in science is a real phenomenon, as the discussion has shown. In our opinion, this realisation emphasises that history is very crucial for the survival of all sciences, and so the significance of history at any particular point in time could be measured partly in terms of its contributions to the intellectual growth and development of other sciences.

Meanwhile, it has been argued that the natural expansion of history into the territories of other sciences, which brings forth such disciplines as the history of accounting, of astronomy, of biology, of chemistry, of economics, of mathematics, of medicine, of philosophy, of physics, of sociology, of zoology, etc., only tends to fragment and atomises the past so that we are left with nothing but the loose change of history (Gardiner, 1988:1). In view of this, it has been concluded that with this fashionable breeze of specialisation, history ceases to have any status as a separate discipline at all and simply becomes a prefix attached to the various influences upon it (Ibid.). Conversely, we are of the view that the stretching of the historical canvas rather underscores the vitality of history and its impact on nearly, if not absolutely, all aspects of nature and culture and the need for its systematic and serious study both as a separate subject and as a component of the sciences, in order to understand that the universe, and everything in it, is a process in time, and so to get a fair knowledge of our true relation with it and to understand the events and things in it, it is necessary to always adopt a historical perspective. In our basic schools, pupils and students read a variety of subjects, including 
accounting, agriculture, art, biology, business, costing, chemistry, dance, economics, English, food and nutrition, French, geography, horticulture, literature, management, mathematics, music, physics, poetry, religious studies, and many other subjects, all of which have history and, therefore, require historical perspectives for a good understanding of their contents. We are convinced that for the youth of today to be able to do well in their subject areas, progress to advanced educational institutions to further their studies and be successful in these areas, and graduate and contribute meaningfully towards the development of their countries, it is crucial to hold history in high esteem, if, indeed, we are committed to making progress in the various fields of study, and to national development.

We also wish to maintain that in advanced educational institutions, history should be recognised formally as an integral part of science and be appropriately taught in all sciences, because it is only when all the sciences are solidly grafted onto the tree of history that their yields, in terms of efficiency, would be dramatic. Fortunately, some universities, including the universities of Natal, Western Cape and Cape Town, all in South Africa, which Nuttal and Wright (1999:1-2) studied in 1999, have seen history as a 'service discipline' to other sciences, such as medicine, law, public policy, commerce, and science and technology (Ibid., p. 22). These South African universities have been impressing on the lecturers and students in these areas to appreciate that historical perspectives are a necessary part of their fields of specialisation, and that academically trained historians are the most qualified professionals to deliver these perspectives (Ibid.). Also at the Royal Holloway College, the Faculties of Arts and Science offer interdisciplinary programmes with the Faculty of History and Social Sciences (Royal Holloway, University of London, August, 2005:12-14), meaning that in this College, history is fully recognised and treated as an essential element in all disciplines and courses. Again, most local universities in Malaysia offer history in the first year for non-arts courses such as law, management, medicine and information technology (Salleh, Mohamad and Ambotang, 2013, September:1). What is more revealing here is the fact that inasmuch as the various sciences have rich history and need historical perspectives in their practices, those who pursue history could find jobs across the various fields of scientific activity. At any rate, I admit that no historical work is ever absolutely authoritative, ever completely definitive. Basically, every scientific work is no more than a temporary framework, fated to be superseded sooner or later by the works of other scholars (Ajayi, 2003:3). However, if for a time, my theory of historical imperialism in science could provide new insight and contribute to a better understanding of the relationship between history and other sciences, it would have served a worthwhile purpose.

\section{REFERENCES}

\section{Articles in Journals, Magazines and Newspapers}

[1] Adjepong, Adjei. 2013. "The Politics of Theorising in Historical Reconstruction: An Examination of the Views of the Protagonists and Antagonists". Historical Research Letter. Volume 8. pp. 1-18.

[2] Adjepong, Adjei. 2011. "The Image of Pre-Colonial Africa in European Circles". In Eric Sakyi Nketiah, Ed. Distance Forum: An Interdisciplinary Journal of Academic Articles. Vol. 1. London: AuthorHouse. pp. $15-30$.

[3] Adjepong, Adjei, Charles Adabo Oppong and Joseph Udimal Kachim. 2017, April. "Crumpling the Significant Past: Actions and Impressions for the 'Fall' of History". Journal of Educational Management. Volume 8. pp. 237-280.

[4] Akinyemi, Balogun, A.E. Okoye and Prince Famous Izedoumi. 2015. "History and Development of Accounting in Perspective". International Journal of Sustainable Development Research. Vol. 1, No. 2. pp. 14-20.

[5] Berryman, Jack W. 2010, July-August. "Exercise is Medicine: A Historical Perspective". Current Sports Medicine Reports. Volume 9, Number 4. pp. 1-7.

[6] Brandt, Allan M. 1991. "Emerging Themes in the History of Medicine". The Milbank Quarterly. Vol. 69, No. 2. pp. 199-214.

[7] Gemtou, Eleni. 2011. ““"Medicine for Art's Sake”? A Philosophical Study on the Relationship between Medicine, Art and Science". Rupkatha Journal on Interdisciplinary Studies in Humanities. Vol. 3, No. 4. pp. 639-650.

[8] Leggewie, Claus. 2013, July-December. "Thinking in the Future Perfect: Climate Change as Social Change". In Manutshehr Amirpur, Ahmad Hissou and Stefan Weidner, Eds. Art \& Thought/Fikrun wa Fann. Issue 99: Culture and Climate. pp. 13-18. 
[9] Mohammed, Kabir. 2013, July. “The Role of History, Historiography and Historian in Nation Building”. International Journal of Humanities and Social Science Invention. Volume 2, Issue 7. pp. 50-57.

[10] Salleh, Mohamad, Baharom Mohammed and Abdul Said Ambotang. 2013, September. "The Significant of History Curriculum in the Development of Active Citizen: A Critical Analysis of the ICSS History, Malaysia”. International Journal of Scientific and Research Publications. Volume 3, Issue 9. pp. 1-8.

[11] Sodzi-Tettey, Sodzi. 2013, July 27. "Why Ghana won't burn - Supreme Court's ruling notwithstanding”. Daily Graphic. p. 10.

[12] Watch Tower Bible and Tract Society of Pennsylvania. 2012, August. "Gout-Causes and Risk Factors". Awake!. Vol. 93, No. 8. pp. 24-25.

\section{Books}

[13] Abdallah, Ali-Nakyea. 2006. Taxation in Ghana: Principles, Practice and Planning. Accra: Black Mask Limited.

[14] Adae, Rebecca et al. Eds. 2009. Macmillan English Dictionary for Advanced Learners. International Students Edition. London: Macmillan.

[15] Aggarwal, J.C. 2004. Teaching of History: A Practical Approach. Third Revised Edition. Second Reprint. New Delhi: VIKAS Publishing House Pvt. Ltd.

[16] Aidoo, Peter. 2012. Economics Textbook for Senior High Schools in West Africa. Revised Edition. Kumasi: Mar-Keyn Publications.

[17] Ajayi, S. Ademola. 2003. Yahya Jammeh and the Gambian Revolution 1994-2001. Ibadan: StirlingHorden Publishers (Nig.) Ltd.

[18] Appadorai, A. 2003. The Substance of Politics. Eleventh Edition, Third Impression. New Delhi: Oxford University Press.

[19] Barzun, Jacques and Henry E. Graff. 1977. The Modern Researcher. Third Edition. New York: Harcourt Brace Jovanovich, Inc.

[20] Beattie, John. 1977. Other Cultures: Aims, Methods and Achievements in Social Anthropology. London and Henley: Routledge \& Kegan Paul.

[21] Brako, Isaac and Kwame Asah-Asante. 2015. Africa: From Colonialism to Independence. Accra: Black Mask Limited.

[22] Breuning, Marijke. 2007. Foreign Policy Analysis: A Comparative Introduction. First Edition. New York and Basingstoke: Palgrave Macmillan.

[23] Burtt, Edwin Arthur. 2003. The Metaphysical Foundations of Modern Science. Dover Edition Mineola, New York: Dover Publications, Inc.

[24] Bynum, William F., E. Janet Browne and Roy Porter. Eds. 1988. Dictionary of the History of Science. London: Macmillan Education UK.

[25] Caldwell, Wallace Everett. 1965. The Ancient World. Revised Edition. New York: Holt, Rinehart and Winston.

[26] Cohen, Morris R. and Ernest Nagel. 1934. An Introduction to Logic and Scientific Method. New York: Harcourt, Brace and Company, Inc.

[27] Coulter, Edwin M. 1994. The Principles of Politics and Government. Fifth Edition. Madison et al.: WCB Brown \& Benchmark Publishers, 1994.

[28] Crombie, A.C. 1959. Medieval and Early Modern Science. Volume I: Science in the Middle Ages: V XIII Centuries. Revised Second Edition. New York: Doubleday \& Company, Inc.

[29] Curtin, Philip D. Ed. 1971. Imperialism. London: The Macmillan Press Ltd.

[30] Davidson, Roger H. and Walter J. Oleszek. 2004. Congress and Its Members. Ninth Edition. Washington, D.C.: CQ Press.

[31] Essien, Ephraim Stephen. 2008. Philosophy of Peace and Conflict Beyond the United Nations. Calabar: University of Calabar Press.

[32] Evans, Ivor H. 1993. The Wordsworth Dictionary of Phrase \& Fable. Hertfordshire: Wordsworth Editions Ltd.

[33] Fields, Lanny B., Russell J. Barber and Cheryl A. Riggs. 1988. The Global Past. Volume One. Boston: Bedford Books, and New York: St. Martin's, 1988.

[34] Finch, Byron J. 2006. Operations Now: Profitability, Process and Performance. Second Edition. Boston: McGraw-Hill/Irwin.

[35] Foucault, Michel. 1970. The Order of Things: An Archaeology of the Human Sciences. English Edition. London and New York: Routledge Classics. 
[36] Gabriel, A.O.I., R.L. Fagbenle and J.M. Jaja. 1998. The History of Science and Technology in Perspective. Ibadan: Afrika-Link Books.

[37] Gay, Peter and Gerald J. Cavanaugh. 1972. Historians at Work. Volume I. New York et al.: Harper \& Row, Publishers, Inc., 1972.

[38] Gay, Peter and R.K. Webb. 1973. Modern Europe. New York et al.: Harper \& Row Publishers.

[39] Giner, Salvador. 1972. Sociology. London: Martin Robertson, \& Company Ltd.

[40] Gorman, William. Ed. 1952. The Great Ideas: A Syntopicon of Great Books of the Western World. Volume I. Chicago et al.: Encyclopaedia Britannica.

[41] Gould, J.D. 1972. Economic Growth in History: Survey and Analysis. London: Methuen \& Co. Limited.

[42] Greenberg, Marvin Jay. 1984. Euclidean and Non-Euclidean Geometries: Development and History. Second Edition. San Francisco: W.H. Freeman and Company.

[43] Harré, R. 1972. The Philosophies of Science: An Introductory Survey. London: Oxford University Press.

[44] Hawking, Stephen W. 1989. A Brief History of Time: From the Big Bang to Black Holes. Bantam Edition. London: Transworld Publishers.

[45] Hobson, John A. 1902. Imperialism: A Study. New York: James Pott \& Company.

[46] Hockett, Homer Carey. 1961. The Critical Method in Historical Research and Writing. Fifth Printing. New York: The Macmillan Company.

[47] Honderich, Ted. Ed. 1984. Philosophy Through Its Past. Middlesex et al.: Penguin Books.

[48] Hughes, J. Donald. 2001. The Environmental History of the World: Humankind's Changing Role in the Community of Life. London: Routledge.

[49] Huxley, Julian. 1953. Evolution in Action. Middlesex: Penguin Books Ltd.

[50] Jain, Naveen Chand. 2010. Dictionary of Banking. Second Edition. Delhi: A.I.T.B.S. Publishers, India.

[51] James, William. 1971. The Moral Equivalent of War and Other Essays. Edited by John K. Roth. First Torchbook Edition. New York et al.: Harper \& Row, Publishers Inc.

[52] Knight, David. 1996. Humphry Davy, Science and Power. Cambridge: Cambridge University Press.

[53] Krogh, David. 1996. Biology: A Guide to the Natural World. Second Edition. Upper Saddle River, New Jersey: Prentice Hall.

[54] Kumekpor, Tom K.B. 1999. Research Methods and Techniques of Social Research. Soft Cover Edition. Accra: SonLife Printing Press \& Services.

[55] Lewis, W. Arthur. 1965. Theory of Economic Growth, Eighth Impression. London: George Allen \& Unwin Ltd.

[56] Link, F. 1969. Eclipse Phenomena in Astronomy. Berlin, Heidelberg and New York: Springer-Verlag.

[57] Lucas, C.W. and R.T. James. 1972. New Mathematics for Senior Students: Mathematics II. Revised and Metricated Edition. Melbourne: Thomas Nelson (Australia) Ltd.

[58] Lundberg, George A. 1949. Social Research. London: Longman, Green and Co.

[59] Magee, Bryan. 1973. Popper. London: Fontana/Wm. Collins Sons \& Co. Ltd.

[60] Maner, Martin. 1996. The Spiral Guide to Research Writing. California: Mayfield Publishing Company.

[61] Marfo-Yiadom, Edward, Stephen Asante and George Tackie. 2012. Introduction to Financial Accounting $\&$ Reporting. Cape Coast: University of Cape Coast Press.

[62] Marwick, Arthur. 1993. The Nature of History. Third Edition. Hampshire and London: The Macmillan Press Ltd.

[63] Matson, Archie. 1975. The Waiting World: Or What Happens at Death. London: Turnstone Books.

[64] McCall, Daniel F. 1969. Africa in Time-Perspective: A Discussion of Historical Reconstruction from Unwritten Sources. New York: Oxford University Press.

[65] Miles, M.B. Miles M. Huberman. 1994. Qualitative Data Analysis: An Expanded Source Book. Second Edition (Thousand Oaks, CA: Sage.

[66] Needham, Joseph. 1982. Science in Traditional China: A Comparative Perspective. Second Printing. Cambridge, Massachusetts: Harvard University Press and Hong Kong: The Chinese University Press.

[67] Novick, Peter. 2001. The Holocaust and Collective Memory: The American Experience. Paperback Edition. London: Bloomsbury Publishing Plc.

[68] Palmer, R.R. and Joel Colton. 1964. A History of the Modern World. Second Edition. New York: Alfred A. Knopf.

[69] Phillips, Claude S. 1984. The African Political Dictionary. Santa Barbara: ABC-Clio, Inc., and Oxford: Clio Press Ltd. 
[70] Renier, G.J. 1950. History: Its Purpose and Method. London: George Allen \& Unwin Ltd.

[71] Rowse, A.L. 1946. The Use of History. London: Hodder \& Stoughton Limited.

[72] Russell, Bertrand. 1972. Wisdom of the West: A Historical Survey of Western Philosophy in Its Social and Political Setting. Edited by Paul Foulkes. New York: Crescent Books, Inc.

[73] Ryle, Gilbert. The Concept of Mind. Fourth Printing. New York: Barnes \& Noble, 1962.

[74] Safra, Jacob E. and Ilan Yeshua. Eds. 2003. The New Encyclopadia Britannica. Volumes 3, 6 and 20. Fifteenth Edition. Chicago: Encyclopædia Britannica, Inc.

[75] Schmitt, Bernadotte. 1960. The Fashion and Future of History. Ohio: Cleveland.

[76] Schumpeter, Joseph. 1951. Imperialism and Social Classes: Two Essays by Schumpeter. Translated by Heinz Norden. New York: Macmillan Books, Inc.

[77] Singh, Yogesh Kumar. 2006. Fundamental of Research Methodology and Statistics. New Delhi: New Age International (P) Limited, Publishers.

[78] Smith, Edward Conrad and Zurcher, Arnold John. Eds. 1955. Dictionary of American Politics. New York: Barnes \& Noble Inc.

[79] Stanlis, Peter J. 1965. Edmund Burke and the Natural Law. Ann Arbor Paperbacks First Edition. Michigan: The University of Michigan Press and Toronto: Ambassador Books Limited.

[80] Storer, Norman W. 1966. The Social System of Science. New York: Holt, Rinehart and Winston, Inc.

[81] Sullivan, Walter. 1966. We Are Not Alone: The Search for Intelligent Life on Other Worlds. Revised Edition. New York, Toronto and London: McGraw-Hill Book Company.

[82] Sultz, Harry A. and Kristina M. Young. 2004. Health Care USA: Understanding Its Organization and Delivery. Fourth Edition. Sudbury, Massachusetts, et al.: Jones and Bartlett Publishers, Inc.

[83] Tayler, R.J. 1970. The Stars: Their Structure and Evolution. London and Winchester: Wykeham Publications (London) Limited.

[84] Teggart, Frederick John. 1960. Theory and Processes of History. Berkeley and Los Angeles: University of California Press.

[85] Tosh, John. 1986. The Pursuit of History: Aims, Methods and New Directions in the Study of Modern History. Fourth Impression. London and New York: Longman Group Limited.

[86] Tosh, John with Sean Lang. 2006. The Pursuit of History: Aims, Methods and New Directions in the Study of Modern History. Fourth Edition. Harlow: Pearson Education Limited.

[87] Walker, Peter M.B. Ed. 1995. The Wordsworth Dictionary of Science and Technology. Hertfordshire: Wordsworth Editions Ltd.

[88] Walker, Samuel and Charles M. Katz. 2002. The Police in America: An Introduction. Fourth Edition. New York: McGraw-Hill Higher Education.

[89] Webster's Reference Library. 2002. Students' Companion. New Edition. New Lanark, Scotland: Geddes \& Grosset.

[90] Wilks, Ivor. 1996. One Nation, Many Histories: Ghana Past and Present. Accra: Ghana Universities Press.

[91] Winner, David. 2005. Those Feet: A Sensual History of English Football. London: Bloomsbury Publishing Plc.

\section{Chapters, Forewords, Introductions and Prefaces in Books and Encyclopedias}

[92] Adjepong, Adjei. 2014. "What is History?: Searching for an Appropriate Definition for the Science of the

[93] Mises, Ludwig von. 1991. "Social Science and Natural Science”. In Richard M. Ebeling, Ed. Champions of Freedom: Austrian Economics: A Reader: The Ludwig von Mises Lecture Series. Volume 18. Hillsdale, Michigan: Hillsdale College Press. pp. 92-109.

[94] Mudimbe, V.Y. 2008. "Invention and Images of Africa". In Joseph C. Miller, Ed. New Encyclopedia of Africa. Detroit et al.: Charles Scribner's Sons. pp. xxxiii-xxxviii.

[95] Oakeshott, Michael. 1936. "History and the Social Sciences". The Social Sciences. London: Institute of Sociology. pp. 71-81.

[96] Porter, Roy. 1994. “Astronomy”. In Roy Porter, Ed. The Biographical Dictionary of Scientists. Second Edition. New York: Oxford University Press; and London: Helicon Publishing Limited. pp. xi-xvi.

[97] _. 1994. "Mathematics". In Roy Porter, Ed. The Biographical Dictionary of Scientists. Second Edition. New York: Oxford University Press; and London: Helicon Publishing Limited. pp. xi-xvi.

[98] Sawyer, W. Warwick. 1962. "The Teaching of Mathematics”. In Ernest Stabler, Ed. The Education of the Secondary School Teacher. Middletown: Wesleyan University Press. pp. 209-233. 
[99] Tsikata, Fui S. 1991. "Towards an Agenda of Constitutional Issues under the Kwame Nkrumah Regime". In Kwame Arhin. The Life and Work of Kwame Nkrumah. Accra: Sedco Publishing Limited. pp. $211-219$.

[100]Van Urk, Hero. 1992. "Foreword". In Nancy Duin and Jenny Sutcliffe. A History of Medicine: From Prehistory to the Year 2020. Morgan Samuel Editions. New York: Barnes \& Noble Books.

[101]Vansina, J, R. Mauny and L.V. Thomas. 1964. "Introductory Summary". In J. Vansina, R. Mauny and L.V. Thomas, Eds. The Historian in Tropical Africa. London, Ibadan and Accra: Oxford University Press.

[102]Watson, Fletcher G. 1962. "The Teaching of Science". In Ernest Stabler, Ed. The Education of the Secondary School Teacher. Middletown: Wesleyan University Press. pp. 191-208.

\section{Internet Materials}

[103]Aybar, Juan Carlos Ocaña. “Colonialism and Imperialism”. Retrieved August 5, 2017, from https://www.slideshare.net/mobile/historiasiglo20/colonialism-and-imperialism.

[104]Beattie, Andrews. 2010, February 21. "The History of Money: From Barter to Banknotes". Retrieved March 23, 2013, from http://www.investopedia.com/articles/07/roots_of_money.asp.

[105]Evans, J.C. "Theories in Science". Retrieved September 9, 2010, from http://physics. gmu.edu/ jevans/astr103/CourseNotes/science_theoriesInScience.html.

[106]Facchi, Giorgio. "The Meaning of History". Retrieved September 17, 2017, from http://www.inif. ucr.ac.cr $>$ recursos $>$ docs $>$ th...

[107]Harper, Douglas. "Theory”. Online Etymology Dictionary. Retrieved September 9, 2010, from http://www.etymonline.com/index.php?term=theory.

[108]Hirst, K. Kris. 2017, February 28. "What is History? - A Collection of Definitions". Retrieved September 17, 2017, from https://www.thoughtco.com/what-is-history-collection-of-definitions-171282.

[109]“Historical Quotes”. Retrieved July 29, 2012, from http://www.activehistory.co.uk/historical_ quotations.htm.

[110] "Imperialism - Case Study: Nigeria". Retrieved August 5, 2017, from www.murrieta. k12.ca.us $>$ lib5 $>$ Domain.

[111]Maxwell, Michael G. "The Uses of History: Why Bother with History?". Retrieved May 16, 2012, from www.studentsfriend.com/onhist/uses.html.

[112]Osabu-Kle, Daniel Tetteh. "African Blood for Imperialist Interests: The First and Second Scrambles for Africa”. Retrieved August 5, 2017, from https://carleton.ca/africanstudies/wp.../ African-Blood-ForImperialist-Interests.pdf.

[113]"Scientific Theory". Retrieved September 9, 2010, from http://www.wordnetweb.princeton. edu/perl/webwn.

[114]Szasz, Ferenc M. 2005. "Historical Quotations”. History News Network. Retrieved June 7, 2013, from http://hnn.us/articles/1328.html.

[115]The Quote Garden. "Quotations about History". Retrieved June 7, 2013, from http://www. quotegarden.com/history.html.

[116]“The Science in Social Sciences". Retrieved September 1, 2017, from press.princeton. edu>chapters.

[117] “Theory". Retrieved September 9, 2010, from www.wordnetweb.princeton.edu/perl/webwn.

[118]Underwood, Robert Milton, Jr. 2008. "Defining History". Retrieved September 17, 2017, from "Unit 1: The Definition and History of Psychology". Retrieved October 201, 2017, from https:// www.saylor.org $>$ site $>2011 / 01$

[119]“Why Study History”. Retrieved July 26, 2012, from http://www.historyguide.org/guide/ study.html.

\section{Interviews (Personal and Telephone)}

[120]Abraham, Kow Kwegya Amissah. Aged 36 years, Lecturer in Philosophy, Department of Classics and Philosophy, University of Cape Coast, Cape Coast, Ghana. Personal Interview: August 4, 2017, Cape Coast.

[121]Attobrah, Emmanuel. Aged 25 years, Economics Graduate and National Service Personnel (Teaching Assistant), Department of Economics, University of Cape Coast, Cape Coast, Ghana. Telephone Interview: August 23, 2017.

[122] Awuku, Romeo Xorse. Aged 23 years, Accounting Graduate and National Service Personnel, College of Distance Education, University of Cape Coast, Cape Coast, Ghana. Personal Interview: August 22, 2017, Cape Coast.

[123]Bosu, Dr. Leticia. Aged 36 years, Lecturer in Accounting, Department of Business and Social Sciences Education, University of Cape Coast, Cape Coast, Ghana. Personal Interview: August 24, 2017, Cape Coast. 


\section{Published Official Documents}

[124]Faculty of Arts, University of Cape Coast. 2013. Faculty Brochure, 2013-2016. Cape Coast: University of Cape Coast Press.

[125]Nestle Group. 2012, February 15. "Consolidated Financial Statements of the Nestle Group 2011" and "145th Financial Statements of Nestle S.A."

[126]Royal Holloway College, University of London. 2005, August. College Brochure. University of Cape Coast. 2011. "Ghana Universities Staff Superannuation Scheme Management Board Financial Report 2011 ”.

\section{Software Application}

[127]Princeton University. 2006. English Dictionary. Princeton University Press.

\section{Unpublished Books, Papers and Theses}

[128]Akakpo, Victor Kodjo Atta. 2013. Principles, Concepts and Practice of Taxation. Fourth Edition.

[129]Kwanda Series. 2013, October. Principles of Economics. Vol. 1.

[130]Mosvold, Reidar. 2005. "Mathematics in Everyday Life: A Study of Beliefs and Actions". Ph.D. thesis submitted to the Department of Mathematics, University of Bergen.

[131]Nuttal, Tim and John Wright. November, 26-28, 1999. "Probing the Predicaments of Academic History in Contemporary South Africa". Paper for the 'International Conference on New African Perspectives: Africa, Australasia and the Wider World at the End of the $20^{\text {th }}$ Century', Organised by The African Studies Association of Australasia and the Pacific, at Perth, Australia.

[132] Yakubu, Alidu Mohammed and Alex Addae Korankye. 2004. Economics Textbook for Senior Secondary Schools. Third Revision.

\section{Unpublished Official Documents}

[133]Assinman Rural Bank Limited. 2012. “Annual Report 2012”.

[134]Department of Economics, University of Cape Coast. "Course Descriptions”. Obtained on August 24, 2017.

\section{AUTHOR'S BIOGRAPHY:}

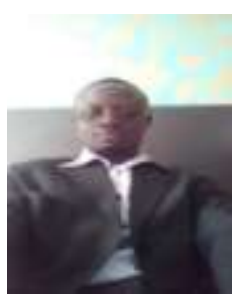

Adjei Adjepong obtained his B.A. (HISTORY) and M.Phil (HISTORY) degrees from the University of Cape Coast, Ghana. He is currently a Lecturer in the Department of History, University of Cape Coast. He is the Review Editor of Abibisem: A Journal of African Culture and Civilisation based in the Department of History at the University of Cape Coast. He is also a member of the Editorial Board for Distance Forum: A Multidisciplinary Journal of Academic Article sand the Director of Research for Centre for Policy Research and Training (CEPRAT Ghana).He has been engaged in research into migration into Ghana and immigration control, and migrations and expulsion in Africa. He has also researched into the application of theories in historical reconstruction, the role of African women in the political development of pre-colonial Africa, and the contemporary significance of the study of History as a discipline.

Citation: Adjei Adjepong. "Historical Imperialism in Science: A Theory of the Relationship between History and Other Disciplines". International Journal of History and Cultural Studies (IJHCS). vol 4, no. 1, 2018 , pp. 10-46. doi:DOI: http://dx.doi.org/ 10.20431/2454-7654.0304002.

Copyright: (C) 2018 Authors. This is an open-access article distributed under the terms of the Creative Commons Attribution License, which permits unrestricted use, distribution, and reproduction in any medium, provided the original author and source are credited. 